\title{
Implication for Cancer Stem Cells in Solid Cancer Chemo-Resistance: Promising Therapeutic Strategies Based on the Use of HDAC Inhibitors
}

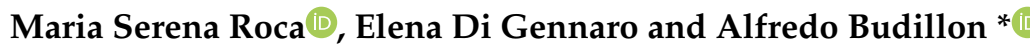 \\ ExperimentalPharmacology Unit, Istituto Nazionale Tumori-IRCCS-Fondazione G. Pascale, 80131 Naples, Italy \\ * Correspondence: a.budillon@istitutotumori.na.it; Tel.: +39-081-5903292
}

Received: 17 May 2019; Accepted: 20 June 2019; Published: 26 June 2019

\begin{abstract}
Resistance to therapy in patients with solid cancers represents a daunting challenge that must be addressed. Indeed, current strategies are still not effective in the majority of patients; which has resulted in the need for novel therapeutic approaches. Cancer stem cells (CSCs), a subset of tumor cells that possess self-renewal and multilineage differentiation potential, are known to be intrinsically resistant to anticancer treatments. In this review, we analyzed the implications for CSCs in drug resistance and described that multiple alterations in morphogenetic pathways (i.e., Hippo, Wnt, JAK/STAT, TGF- $\beta$, Notch, Hedgehog pathways) were suggested to be critical for CSC plasticity. By interrogating The Cancer Genome Atlas (TCGA) datasets, we first analyzed the prevalence of morphogenetic pathways alterations in solid tumors with associated outcomes. Then, by highlighting epigenetic relevance in CSC development and maintenance, we selected histone deacetylase inhibitors (HDACi) as potential agents of interest to target this subpopulation based on the pleiotropic effects exerted specifically on altered morphogenetic pathways. In detail, we highlighted the role of HDACi in solid cancers and, specifically, in the CSC subpopulation and we pointed out some mechanisms by which HDACi are able to overcome drug resistance and to modulate stemness. Although, further clinical and preclinical investigations should be conducted to disclose the unclear mechanisms by which HDACi modulate several signaling pathways in different tumors. To date, several lines of evidence support the testing of novel combinatorial therapeutic strategies based on the combination of drugs commonly used in clinical practice and HDACi to improve therapeutic efficacy in solid cancer patients.
\end{abstract}

Keywords: cancer stem cells; solid cancer; chemo-resistance; HDAC inhibitors

\section{Introduction}

Drug resistance is a well-known phenomenon that arises when a disease becomes tolerant to treatment. This concept was described first in bacteria when they became resistant to antibiotics, but since then, this phenomenon has been observed in other diseases, including cancer. Although many types of cancers are initially susceptible to antitumor approaches including chemotherapy and target-therapy and immunotherapy, over time, cancers can develop resistance through several mechanisms, such as DNA mutations or metabolic changes that promote drug inhibition and degradation [1]. Solid tumors are biologically complex structures with strong intratumor heterogeneity that arises among cancer cells within the same tumor as a consequence of genetic changes, environmental differences, and epigenetic and reversible changes in cell features [2]. Two main conceptual frameworks have been elaborated to conceptualize the link between intratumor heterogeneity and therapy resistance [3]. The first and most supported idea is clonal evolution, where a single mutated cell creates a tumor and over time acquires additional mutations, resulting in several subpopulations with 
evolutionary advantages [4]. An example of this comes from the analysis of circulating tumor DNA in the blood of colorectal cancer (CRC) patients with primary or acquired resistance to epidermal growth factor receptor (EGFR) blockade [5]. Siravegna and colleagues exploited the circulating tumor DNA to genotype colorectal tumors and tracked clonal evolution during treatment with EGFR-specific antibodies, discovering that the percentage of mutated KRAS clones declines in blood when EGFR-specific antibodies are withdrawn. This result suggests that resistant cell populations are highly dynamic and that specific resistant clones arise in specific therapeutic conditions [5].

The second concept is the cancer stem cell (CSC) model. In the last decade, several lines of evidence have suggested the presence of CSCs within the plethora of heterogeneous cells in solid cancers. The CSC paradigm implies that the tumor is organized into a hierarchy of subpopulations of tumorigenic CSCs and their non-tumorigenic progeny [6]. Among other described CSC features, self-renewal potential and the capability to generate progenitor/daughter cells with various degrees of differentiation make CSCsresponsible for tumor heterogeneity, drug resistance and tumor relapse (Figure 1) [7]. However, although several papers have identified CSCs as being responsible for drug resistance, the evidences are based on the identification and characterization of CSCs made with numerous non-homogeneous experiments that are difficult to compare. Thus, to confirm this theory, different approaches (in vitro, in vivo and in silico) must be implemented. Moreover, understanding the features and the complex signaling mechanisms that underlie the CSC state is a key point in highlighting new possible therapeutic strategies to target CSCs and to overcome resistance (Figure 1).

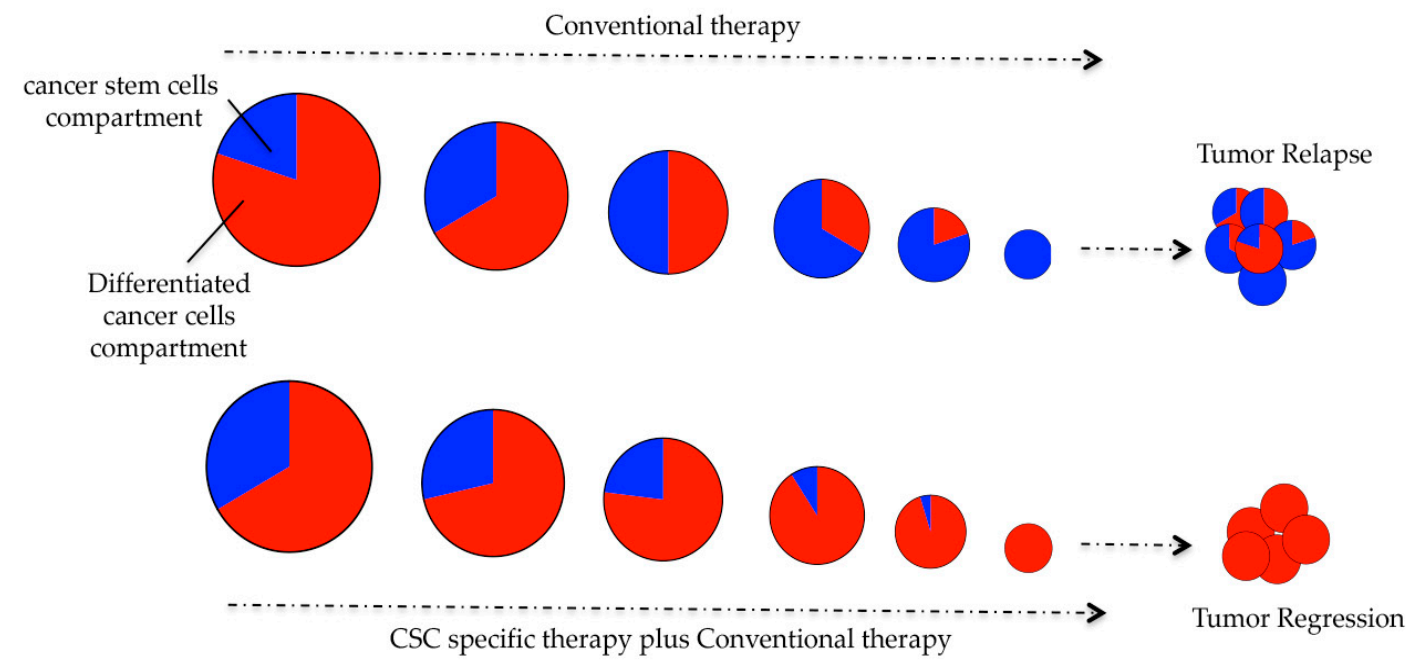

Figure 1. Cancer stem cells (CSCs) model of drug resistance:CSCs are responsible for tumor heterogeneity, drug resistance and tumor relapse. Indeed, they may survive chemotherapy lead to tumor relapse. Only by taking advantages of a CSCs specific targeted therapy, the outcome could result in tumor regression and patients' complete survival.

To date, it is widely recognized that alterations of the "epigenome" are therapeutically relevant as well as DNA mutations. Indeed, in contrast to DNA mutations, "epimutations" must be actively maintained through DNA replication for their dynamic nature; thus, their functional effects are reversible and, consequently, targetable [8,9].

Increasing evidence supports the significance of the epigenetic regulation of CSCs' features [10]. DNA methylation as well as histone acetylation are two epigenetic modifications that participate in the modulation of expression of many genes, regulating important cellular activities such as proliferation, differentiation and migration. While the role of DNA methylation in CSCs is relatively well established, the role of histone and non-histone protein acetylation is still not completely clear.

It has been suggested that, globally, hypoacetylated chromatin is associated with cancer [11]. In detail, as reviewed by Liu et al. [12], the dysregulation of two classes of enzymes, histone 
acetyltransferases (HAT) and histone deacetylases (HDAC), implicated in the regulation of acetylation levels is related to carcinogenesis and the regulation of the stemness properties of both normal and cancer cells. Thus, acetylation and deacetylation of histones and non-histone proteins regulate important signaling pathways involved in the maintenance of cancer stem-like cell traits such as self-renewal or differentiation.

In invasive breast cancer patients, Sulaiman et al. recently observed a direct link between HDAC expression and CSCs. By analyzing 887 samples, they found that high Wnt and HDAC activity was associated with estrogen receptor 1 (ESR1) and progesterone receptor (PGR) repression, poor survival and increased relapse. Interestingly, clinically achievable doses of Wnt, HDAC, and ESR1 inhibitors were able to inhibit both bulk and CSC subpopulations, inducing the differentiation of CSCs in non-CSCs without affecting normal mammary epithelial cells (MCF-10A) [13]. The overexpression of individual HDACs has been correlated to predict poor patients' prognosis independently of tumor type and disease stage and a role of specific HDACs has been also reported in CSCs. The genetic knockdown of individual isoforms such as HDAC1, 2, 3 and 6 have been shown to induce cell cycle arrest and apoptosis in several tumor types including breast, lung, colon cancer and leukemia as review by West et al. [14]. Witt et al. [15] taking advantage of two independent pairs of genetically matched immortalized breast cancer cell lines, derived one from normal human breast precursor epithelial cells with a mixed luminal-myoepithelial phenotype resembling CSC characteristics, and the one from normal human mammary epithelial cells that exhibit a more differentiated myoepithelial phenotype, demonstrating that HDAC1 and HDAC7 play an essential role in the stem-like phenotype, maintaining the CSC population in breast and ovarian cancer models. Another work reported that the levels of HDAC 1, 7 and 8 were overexpressed in pancreatic ductal adenocarcinoma (PDAC) compared to those of adjacent non-tumor tissues and that patients with high levels of HDAC 1, 7 or 8 had significantly worse overall survival compared to those with low expression levels [16]. A specific role of HDAC8 was also demonstrated in breast cancer, where a selective HDAC8 inhibitor suppressed Notch 1 expression [17]. Moreover, An et al. reported that, in triple negative breast cancer, HDAC8 induced cell migration by Hippo-Yap signaling. In detail, HDAC8 suppressed the phosphorylation of YAPSer127 to promote its nuclear localization [18].

In contrast, Zimberlin et al. taking advantage of a mouse model in which HDAC1 and HDAC2 were simultaneously deleted in the intestine of adult mice, showed a rapid loss of intestinal homeostasis and a decrease in stem-like features when both HDACs were deleted [19]. This latter observation suggests a rationale for the intestinal side effects often observed during treatment with HDAC inhibitors (HDACi). Similarly, Jamaladdin et al. by conditional knock-down in embryonic stem cellsdemonstrated the essential role of HDAC1 and 2 in cellular proliferation and stem cell self-renewal throughthe regulation of key pluripotent transcription factors [20]. Indeed, severe phenotypes were observed following specific deletion of both HDAC1 and HDAC2 in the heart, brain, smooth muscle and neuronal endocrine cells, suggesting a fundamental role for these HDACs in organ maintenance [21]. However, the hypothesis of positive or negative effect exerted by HDACi on normal stem cells is controversial. In this regard, Yusoff and colleagues published a systematic review about preclinical studies evaluating the organ protection effects of HDACi. They conclude that HDACi reduce mortality in experimental models by conferring multi-organ protection, often following a single treatment administered in some cases post injury, suggesting the design of early phase clinical trials in order to confirm the protective role exerted by these agents [22].

From this perspective, the increased dependency of tumor cells on HDACs and their upregulation during transformation could help identifying the therapeutic window's width of HDACi. At the same time, we should be aware of the potential toxicity induced by this class of agent. 
Below, we provide an overview of promising therapeutic strategies based on HDACi, to sensitize CSCs to antitumor approaches including chemotherapy and target and immunotherapy. We first outlined the multiple alterations within morphogenetic pathways that show a critical role in CSC plasticity and are potentially targeted by HDACi. Then, considering all intrinsic and extrinsic features of CSCs responsible for chemo-toxicity escape, we discuss the capability of HDACi, alone or in combination, to overcome chemo-resistance.

\section{Morphogenetic Pathways Are Dysregulated in Solid Cancers}

As extensively demonstrated, stem cell proliferation and cell fate are under the control of several morphogenetic pathways. Among them, we focused on those that have been extensively characterized in cancer: Wnt/ $\beta$-catenin, Notch, Hedgehog, TGF- $\beta / B M P$, JAK-STAT and Hippo pathways (Figure 2). These pathways can be altered in solid cancer and participate in phenomena such as drug resistance. However, these pathways undertake a different role depending on which solid cancer is considered. To identify specific morphogenetic pathways that are more relevant than others in specific solid tumors, we performed a bioinformatics analysis, taking advantage of 16 public solid tumor expression datasets (Table 1 reports The Cancer Genome Atlas (TCGA) Id, the sample size and the patient status for each dataset) by using the online tool R2 Genomics Analysis and Visualization Platform (https://hgserver1.amc.nl/cgi-bin/r2/main.cgi). R2 calculates, for all the genes in the differentiation-related KEGG pathways (718), whether they are differentially expressed considering overall survival, which is the best endpoint to consider to compare multiple cancer types with the goal of identifying common themes that transcend the tissue of origin and may inform precision oncology, as described in a recent publication by Liu et al. [23].

We are aware that our pan-cancer systematic analysis is performed across all TCGA tumor types without considering patients clinical features. In details, we did not considered age of diagnosis and grade, when available in TCGA datasets. Thus we anticipated that ouranalysis hassome limitations.

In a subsequent calculation, the overrepresentation of these genes in the individual pathways was determined. A valuewas reported depending on how many related genes were identified withineach pathway as compared with all 718 differentiation-KEGG pathways analyzed. In detail, we tested the significance of the 6 chosen morphogenetic pathways described above. In Table 1, the significance values are reported for the 6 pathways for each solid cancer, and the differences among the 6 pathways analyzed are represented by a color scale. From the resulting list, it is obvious that any specific pathway can be indicated as most relevant in the poor prognosis of patients for all cancer types. Notably, the Hippo pathway had a strong over-representation in patients with a poor prognosis among solid tumors (first in 7/16 tumors), playing a critical role in pancreatic, prostate, stomach adenocarcinomas, lung squamous and cervical cell carcinomas, sarcoma and skin cutaneous melanoma. Similarly, the Wnt/ $\beta$-catenin pathway seems to play a very important role, representing the most important pathway in 4/16 cases, such as mixed colon adenocarcinoma, liver hepatocellular, head and neck and bladder urothelial carcinomas and third most-important pathway in 8/16 cases (Table 1). Jak/ STAT resulted as key pathway in rectum adenocarcinoma and glioblastoma, while TGF $\beta$ in lung adenocarcinoma, Notch in kidney renal clear cell carcinoma and finally Hedgehog in breast invasive cancers. 
Table 1. Prevalence of CSCs-activated signaling pathways in solid tumors accordingly with outcome: Results obtained by R2 on line tool. Clustering the patients in dead and alive for each solid cancer, the values are indicative of how enriched in dead patients are the Hippo, Wnt, Jak/STAT, TGFb, Notch, Hedgehog pathways, based on gene expression data. The values are between 0 and 1 where 0 is the best over-representation. The color scale (from violet to white) groups the 6 CSCs pathways from the highest to the lowest enriched, among each TCGA (The Cancer Genome Atlas) dataset.

\begin{tabular}{|c|c|c|c|c|c|c|c|c|c|c|}
\hline \multirow[b]{2}{*}{ Solid Cancer } & \multirow[b]{2}{*}{ TCGA_Id } & \multirow[b]{2}{*}{ Whole Sample } & \multicolumn{2}{|c|}{ Patient Status } & \multicolumn{6}{|c|}{ CSCs-Activated Signaling Pathways } \\
\hline & & & Alive & Dead & Hippo & Wnt & Jak/STAT & TGF & Notch & Hedgehog \\
\hline Mixed Colon Adenocarcinoma & COAD & 174 & 140 & 15 & 0.880 & 0.310 & 0.470 & 0.640 & 0.950 & 0.910 \\
\hline Rectum adenocarcinoma & READ & 95 & 87 & 7 & 0.360 & 0.800 & 0.00041 & 0.150 & 1.000 & 0.360 \\
\hline Pancreatic adenocarcinoma & PAAD & 178 & 119 & 59 & 0.270 & 0.330 & 0.430 & 0.550 & 0.390 & 0.520 \\
\hline Lung Adenocarcinoma & LUAD & 515 & 389 & 126 & 0.900 & 0.300 & 0.400 & 0.210 & 0.800 & 0.420 \\
\hline Lung Squamous Cell Carcinoma & LUSC & 81 & 61 & 19 & 0.390 & 0.530 & 0.610 & 0.440 & 0.580 & 0.620 \\
\hline Prostate Adenocarcinoma & PRAD & 497 & 489 & 8 & 0.016 & 0.300 & 0.670 & 0.210 & 0.360 & 0.360 \\
\hline Stomach adenocarcinoma & STAD & 415 & 336 & 79 & 0.260 & 0.410 & 0.500 & 0.310 & 0.460 & 0.520 \\
\hline Liver Hepatocellular Carcinoma & LIHC & 371 & 282 & 89 & 0.840 & 0.510 & 0.580 & 0.680 & 0.550 & 0.680 \\
\hline Kidney Renal Clear Cell Carcinoma & KIRC & 533 & 363 & 160 & 0.780 & 0.620 & 0.810 & 0.120 & 0.080 & 0.950 \\
\hline Head Neck Squamous Cell Carcinoma & HNSC & 520 & 353 & 167 & 0.140 & 0.006 & 0.030 & 0.930 & 0.440 & 0.500 \\
\hline Cervical Squamous Cell Carcinoma & CESC & 305 & 244 & 60 & 0.400 & 0.610 & 0.520 & 0.630 & 0.480 & 0.530 \\
\hline Bladder Urothelial Carcinoma & BLCA & 408 & 300 & 108 & 0.260 & 0.100 & 0.500 & 0.310 & 0.440 & 0.520 \\
\hline Sarcoma & SARC & 259 & 184 & 75 & 0.580 & 0.680 & 0.740 & 0.620 & 0.720 & 0.750 \\
\hline Breast Invasive Carcinoma & BRCA & 1097 & 992 & 104 & 0.100 & 0.300 & 0.400 & 0.670 & 0.800 & 0.000008 \\
\hline Glioblastoma & TARGET_NBL & 153 & 52 & 99 & 0.840 & 0.400 & 0.002 & 0.410 & 0.550 & 0.160 \\
\hline Skin Cutaneous Melanoma & SKCM & 470 & 313 & 156 & 0.360 & 0.500 & 0.580 & 0.410 & 0.550 & 0.600 \\
\hline
\end{tabular}




\subsection{Wnt Signaling}

Wnt signaling is one of the main pathways regulating development and stemness, and it has also been closely related to cancer. The canonical Wnt signaling pathway, which through $\beta$-catenin modulates the expression of specific target genes, is an important regulator of stem cells and CSCs and is aberrantly activated during the development of various human cancers as reviewed by Fodde et al. [24]. Gain-of-function mutations of the CTNNB1 gene (encoding $\beta$-catenin) and loss-of function mutations of $A P C$ and AXIN genes were identified as the main mechanisms associated with Wnt signaling dysfunction in cancers [25]. The role of this pathway in carcinogenesis has been most prominently described for colorectal cancer (CRC). In the gut, the Wnt pathway is essential for sustaining cell proliferation within the crypt base and shows a gradient in expression along the crypt axis. Manipulation of Wnt signaling can drastically alter crypt integrity, while the stimulation of Wnt activity by, for instance, R-spondin leads to crypt proliferation [6], and its inhibition leads to the loss of crypt formation and progenitor offspring [7]. Moreover, the presence of Wnt in conjunction with other morphogenetic pathways is critical for maintaining normal and cancer cycling stem cells and Paneth cells, as reviewed by Reya and Clevers [26].

\subsection{Hippo Pathway}

In mammals, cell-cell junctions and apicobasal polarity are involved in upstream activation of the Hippo cascade. The core of the Hippo pathway is a kinase cascade: the nuclear result is that Lats1/2, nuclear dbf2-related family kinases, phosphorylate two major downstream effectors, Yes-associated protein (YAP) and transcriptional coactivator with PDZ-binding motif (TAZ), resulting in their ubiquitination and proteolysis [27]. Nguyen et al. showed that YAP1 induced transcriptional changes and resulted in age-related prostate tumors in mice [28]. Similarly, Zhang et al. showed a significant upregulation and hyperactivation of YAP in castration-resistant prostate tumors compared to their levels in hormone-responsive prostate tumors. They claimed that the enhanced expression of YAP was able to transform immortalized prostate epithelial cells and promote migration and invasion in both immortalized and cancerous prostate cells [29].

\subsection{Stats}

Stats are a family of transcription factors with additional functions in the cytoplasm, the mitochondria and the nucleus. They participate in chromatin conformation and epigenetic marking in the nucleus. In addition, they affect oxidative metabolism in the mitochondria and in the cytoplasm, and they interact with microtubule components to regulate cellular motility [30]. However, in our bioinformatics analysis, the JAK/STAT pathway was highly represented in glioblastoma and rectum adenocarcinoma (Table 1). Signal transducer and activator of transcription 3 (STAT3) is aberrantly activated in glioblastoma and has been identified as a relevant therapeutic target in this disease and many other human cancers [31]. Moreover, Gangulyand colleagues demonstrated high levels of STAT 3-phosphorylation in Tyrosine 705 and Serine 727 in glioma-initiating cells compared to their differentiating counterparts, suggesting a clear involvement of STAT pathway activation in gliomagenesis [32]. In addition, a strong link between IL-6-STAT3 signaling and O6-methylguanine DNA methyl transferase expression and methylation and to temozolomide sensitivity in glioblastoma was found, suggesting a possible combination therapeutic approach based on IL-6/STAT3 inhibitors [33,34]. Nevertheless, STAT3 is over-activated in many breast cancers, while STAT5 promotes both survival and differentiation of mammary epithelium. Moreover, it is known that, in the context of breast cancer, STAT3 activity can be modulated through STAT5 activity, and their combined functions can have an impact on breast cancer progression [35]. 


\subsection{TGF- $\beta$ Signaling}

TGF- $\beta$ signaling controls the cell cycle, differentiation and the microenvironment in epithelial cells through both the SMAD protein family and non-SMAD signaling pathways. In colon cancer, Yusra et al. showed that the expression levels of TGF- $\beta$ receptor genes, TGFBR1 and TGFBR3, were higher in CD133 positive (+) colon CSCs, suggesting that CD133+ colon CSCs have increased sensitivity to TGF- $\beta$ [36]. They showed high expression of the TGFBR1 gene in the tumor budding structures derived from the mouse xenograft with TGF- $\beta$ transfected cells. Importantly, Yu and colleagues showed that TGFBR2 was responsible for triggering the TGF- $\beta$ signaling pathway through recruitment and phosphorylation of Type I receptor, which has been shown to act as a tumor suppressor by assisting in the regulation of stemness through downregulated signaling effects of the $\mathrm{Wnt} / \beta$-catenin signaling pathway [37].

\subsection{Notch Pathway}

Regarding the Notch pathway, the literature provides many data about its fundamental role in development and maintenance of the hematopoietic system. Less is available on its role in solid cancers. In hematopoiesis, Notch plays a central role in cell fate proliferation and differentiation of stem cells. There is also evidence demonstrating that the Notch pathway can leads hematopoietic stem cells and common lymphoid precursors to undergo T- or B-cell differentiation [38]. Moreover, Notch alteration has been associated with tumorigenesis, since it can be considered, depending on cell model, as an oncogene or a tumor suppressor [39].

\subsection{Hedgehog Pathway}

Finally, the Hedgehog (Hh) pathway is mainly involved in tissue repair, embryonic development, and epithelial-to-mesenchymal transition in cells. In the signaling cascade, Hh ligands, such as Sonic Hedgehog (Shh), Indian Hedgehog (Ihh), and Desert Hedgehog (Dhh), undergo cleavage and produce a signaling protein with dual lipid modifications. Subsequently, the signaling cascade initiated by smoothened (SMO) leads to activation and nuclear localization of GLI transcription factors, which drive the expression of Hh target genes, mostly involved in proliferation, survival, and angiogenesis [40]. This signaling transduction pathway has been shown to be required for self-renewal and proliferation of cerebellar, retinal, and pancreatic CSCs [41]. Recently, Duan et al. have shown that Hh signaling is upregulated in breast cancer cells through nuclear factor- $\mathrm{KB}$ (NF- $\mathrm{kB}$ ) activation and promoter hypomethylation. In addition, overexpression of Shh enhances the self-renewal capacity and migration ability of breast cancer cells and is a poor prognostic indicator in breast cancer [42].

Because of a clear deregulation is described in multiple cancer types, various clinical approaches have been aimed to target the aforementioned pathways. Although several types of inhibitors of the Wnt-pathway are under development as single-agent anticancer therapies, they have not led to exciting results thus far. Indeed, even if PRI-724 (CBP/ $\beta$-catenin antagonist), LGK-974 (Porcupine inhibitor), vantictumab (anti-Frizzled-1/2/5/7/8 antibody), OMP-54F28 (Frizzled-8-Fc decoy fusion protein) and TSA101 (a radiolabeled anti-Frizzled-10 antibody) are all currently in early clinical development, the results obtained in three concluded studies in monotherapy with PRI-724 (NCT01302405), vantictumab (NCT01345201) and OMP-54F28 (NCT01608867) are not very promising [42].

In solid tumors, several clinical trials are ongoing to test the efficacy of two major classes of Notch inhibitors such as $\gamma$-secretase inhibitors, which obstruct Notch receptor cleavage, and monoclonal antibodies that interfere with the Notch ligand-receptor interaction, as reviewed by Venkatesh et al. [38]. Thus far, the best results have been obtained in a clinical trial that ended in 2012, where a $\gamma$-secretase inhibitor (MK-0752) was used in adult patients with advanced solid tumors, mostly gliomas. Only one objective complete response and stable disease longer than 4 months in 10 patients were observed among 113 patients enrolled [43]. 


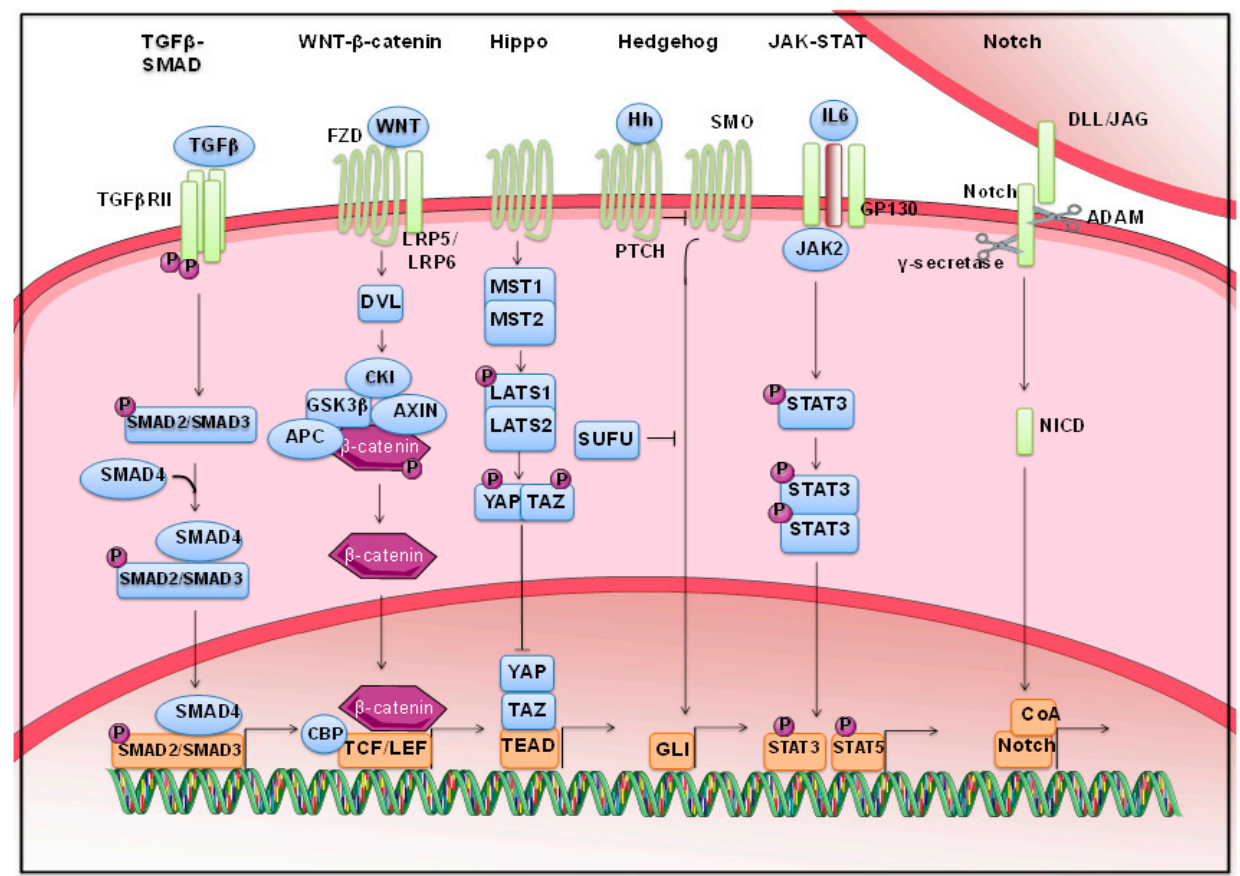

Figure 2. CSCs-activated signaling pathways: Schematic representation of the signaling pathway responsible for induction and maintenance of CSC state. The transcription factors, co-factors, main nodes reported are targetable by drugs. (Adapted from Pattabiraman and Weinberg, Nat Rev Drug Discovery, 2014 [44]).

Limited results have been obtained with vismodegib, an Hh pathway inhibitor, which was approved by the European Medicines Agency (EMA) in 2013 for the treatment of metastatic basal cell carcinoma (BCC) or locally advanced BCC in patients who are not candidates for surgery or radiotherapy. Indeed, the gain in overall survival in these patients compared to standard therapy, is only 0.8 years [42].

Currently, several other attempts are ongoing, targeting CSCs to deplete the tumor; however, to date, no specific CSC targeted therapy is yet available. In contrast, it may be more effective to use an approach based on pushing CSCs to differentiate and on sensitizing them to chemotherapy by modulating their epigenetic profile. Indeed, by highlighting the significance of the epigenetic profile in CSC maintenance, in the next sections we reviewed the role of HDACi to target CSCs, both directly and through the modulation of the morphogenetic pathways described above. Actually, by demonstrating that morphogenetic pathway alterations correlating with poor prognosis often coexist in a solid cancer type, we anticipated the limited efficacy of targeted agents inhibiting a single pathway as reported above. This could shed a new light on therapeutic agents with pleiotropic effect such as HDACi. Therefore, we next discussed how HDACi could play a role in overcoming resistance to some of the most commonly used chemotherapeutics and their ability to enhance specific cancer therapeutic agents by targeting CSCs.

\section{Histone Deacetylase (HDAC) Inhibitors Target Cancer Stem Cells (CSCs) and Morphogenetic Pathways}

It is well known that the morphogenetic pathways described above are frequently dysregulated in cancer by epigenetic mechanisms as reviewed by Munozet al. [45]. Since trichostatin A (TSA), a natural product isolated from Streptomyces hygroscopicus, was described as an HDACi [46], several agents of this class of epigenetic drugs have been synthetized and tested as anticancer agents, both in preclinical and clinical models. HDACi are truly pleiotropic agents, which act through a wide variety of disparate and mutually interactive mechanisms. Indeed, by influencing the chromatin structure, HDACi regulate 
gene expression. Moreover, by acting on non-histone proteins deacetylation, HDACi can also modulate cellular functions independent of gene expression. In this way, HDACi regulate different altered pathways in cancer, such as apoptosis, DNA repair, growth arrest, terminal differentiation, senescence, apoptosis, anti-angiogenesis, anti-metastasis and immune responses, all of which represent hallmarks of cancer and critical characteristics of CSCs [11]. Finally, HDACi have a strong effect on CSCs by pushing them from a stem-like and resistant phenotype to a more differentiated and sensible phenotype (Figure 3).

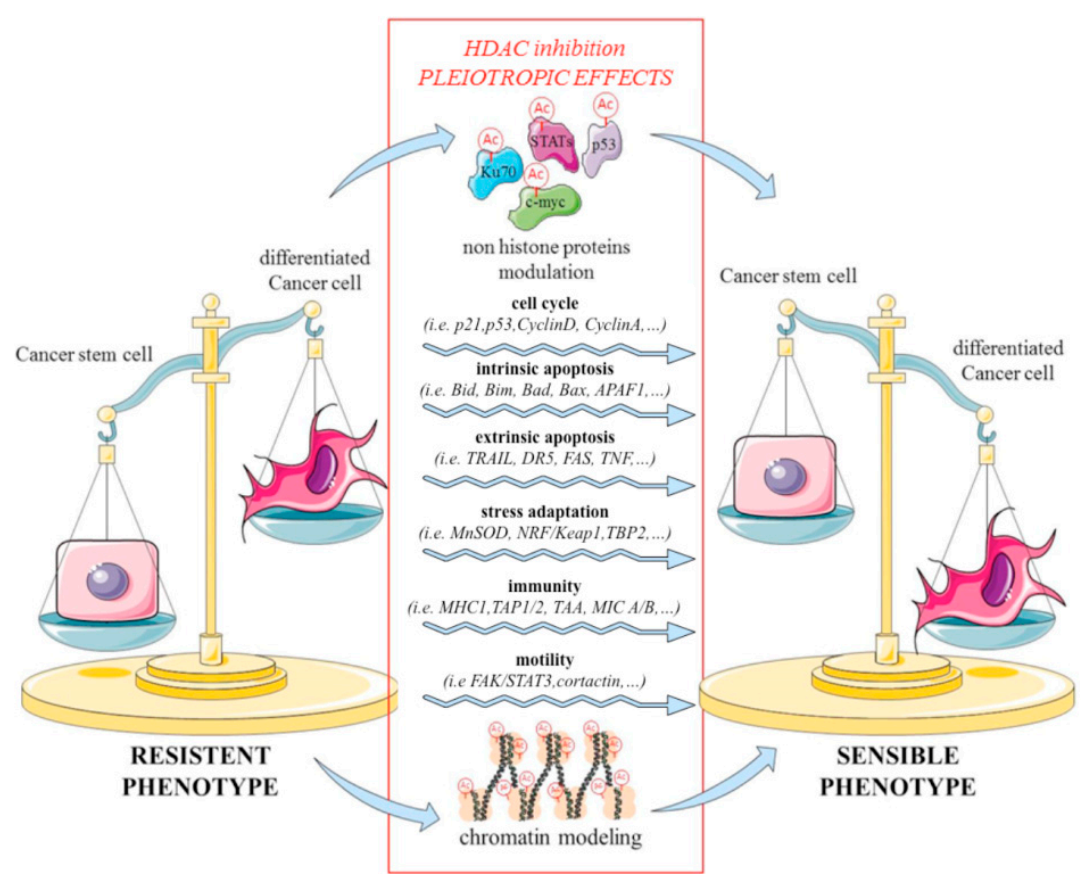

Figure 3. Histone deacetylase inhibitors (HDACi) pleiotropic effects toward CSCs: HDAC are described to modulate several pathways involved in cell cycle, metabolism, stress adaptation, intrinsic and extrinsic apoptosis, motility and immunity through chromatin modeling and non histone proteins modulation. The plasticity of epigenetic regulation makes HDAC inhibition a good strategy to target CSCs chemo-resistant subpopulation in solid cancer pushing the CSCs to differentiate and so gain a chemo-sensible phenotype.

In recent years, we demonstrated that HDACi, such as vorinostat and valproic acid (VPA), were able to induce selective death of the CSC subpopulation in non-small-cell lung cancer (NSCLC) and CRC models, as evaluated by colony and sphere formation assays [47,48].

Similar results were obtained by Salvador et al. who demonstrated that the HDACi abexinostat induced cytotoxicity in 16 breast cancer cell lines (BCLs), as evaluated by Aldefluor and tumorsphere formation assays. They found that abexinostat induced CSC differentiation, identifying the long non-coding RNA Xist (Xinactive specific transcript) as a biomarker that can predict the BCL response to HDACi [49]. In line with these findings, Cai et al. demonstrated that TSA or vorinostat, downregulating HDACs 1, 7 and 8, repressed epithelial to mesenchymal transition (EMT) in PDAC and targeted well-known CSC phenotypes, including resistance to therapy and metastasis. Notably, they also suggested that HDACi such as mocetinostat, which specifically inhibits isoforms 1, 2, 3 and 11 HDACs, were not good candidates for PDAC treatment [16]. Moreover, we obtained preliminary data showing that HDACi sensitized cancer cells to chemotherapeutics by pushing them in a differentiation state in colorectal and prostate cancer cell models by modulating morphogenetic pathways [50].

In addition to the preclinical studies that focused on HDACi and their functional effects on modulating CSC subpopulations, several attempts are aiming to explain the molecular mechanisms underlying HDACi effects of HDACi on them. We most likely believe that HDACi strongly modulate 
the CSC phenotype through their ability to modulate one or more morphogenetic pathway main components, as described above.

Similarly, several data support the close connection between HDAC6 and multiple components of the Wnt, Hippo, TGF $\beta$ and Hh pathways. Concerning the Wnt pathway, two papers showed that HDAC6 inhibition led to a decrease in $\beta$-catenin nuclear localization, resulting in a strong inhibition of cell proliferation [51,52]. In breast cancer, the involvement of HDAC6 in the Hippo pathway-regulating network was demonstrated by downregulation of YAP protein levels [53] and by a strong acetylation and destabilization of the tumor suppressor MST1 [54]. Some evidence suggests that HDAC6 plays a role in theTGF $\beta$-SMAD activation pathway, and thus its inhibition establishes a decrease in EMT induction $[55,56]$. Finally, most recently, it has been shown that HDAC6 inhibition leads to inactivation of Gli1, resulting in glioma cancer cell radio-sensitization [57]. In the same manner, HDAC1 has been shownto be essential for SMAD2-3 and Gli1 transcriptional activation, consequently also quenching related pathways $[58,59]$. As expected, the molecular mechanism becomes complicated when we consider the effect of HDACi, which target more than one HDAC isoform and, simultaneously, more than one morphogenetic pathway.

For example, valproic acid (VPA), a class I- II HDAC inhibitor, is clearly able to inhibit TGF- $\beta$, Yap and Notch signaling by dual suppression of SMAD4 and SMAD3 [60], by depletion of nuclear YAP [61] and by downregulation of the transcription factor Notch1 and its target gene HES-1 [62]. Moreover, it has been reported that the pan-HDAC inhibitor trichostatin A (TSA) and the selective HDAC inhibitor entinostat (isoforms 1, 2 and 3) are able to reduce Wnt pathway activation by induction of DKK1, a negative regulator of $\beta$-catenin [63] and by inhibition of HDAC1-2 [19].

Finally, as VPA and TSA, vorinostat modulates SMAD4 localization and Nocth3 expression [64,65], but Fan and colleagues also showed that a small molecule SMO-HDAC antagonist was able to retain inhibitory activity for Gli transcription induced in SMO-dependent and SMO-independent ways [66]. Furthermore, TSA and domatinostat, two specific class I and II HDAC inhibitors, switched off Gli signaling by downregulating a transcriptional factor of FoxM1 [67] in the first case and by inhibition of HDAC1/2/3 in the second case [68]. However, it should be noted that some papers have reported that VPA treatment is responsible for Wnt pathway activation by $\beta$-catenin nuclear stabilization $[13,69]$.

However, the exact function and interactions governing HDACi activity remain elusive. Thus, further investigationsare necessary to understand the mechanism by whichHDACi target CSCs. Only a clear view of their actions will lead to the identification of a biologically efficacious dose. Thus, it should always be considered that the effects of HDACi depend not only on the cancer type but also on the context, dosing and schedule of treatment. For example, the association of entinostat with the aromatase inhibitor exemestane has been designated as a breakthrough therapy for the treatment of recurrent/metastatic estrogen receptor-positive breast cancer based on the results of a phase II randomized trial [70]. In contrast, the clinical activity of mocetinostat, tested in phase I/II in association with gemcitabine in patients with solid tumors including pancreatic cancer, has been considered insufficient to merit further testing in this setting [71], as well as due to the significant toxicities in the phase II cohort [71].

\section{CSC Chemo-Toxicity Escape Mechanisms}

Cancer drug-resistance can be due to intrinsic or acquired factors. The intratumor heterogeneity of tumor cells and the tumor microenvironment and the presence of cancer stem cells are all intrinsic characteristics involved in cancer drug resistance. But latter, has also been observed in most drug-sensitive tumor types for most classes of drugs as an acquired mechanism.

Several mechanisms of cancer drug resistance are well described in both tumor cells and CSCs, and the most important and targetable ones, such as multidrug resistance [72], resistance to apoptosis program, increased repair of drug-induced DNA damage and quiescence phenotype induction [73], are presented schematically in Figure 4. In addition to the common and well-known mechanisms by which normal stem cells and CSCs overcome drug toxicity, some others have recently been described, 
such as metabolism adaptation or activation of the immune escape program, while others remain to be uncovered.

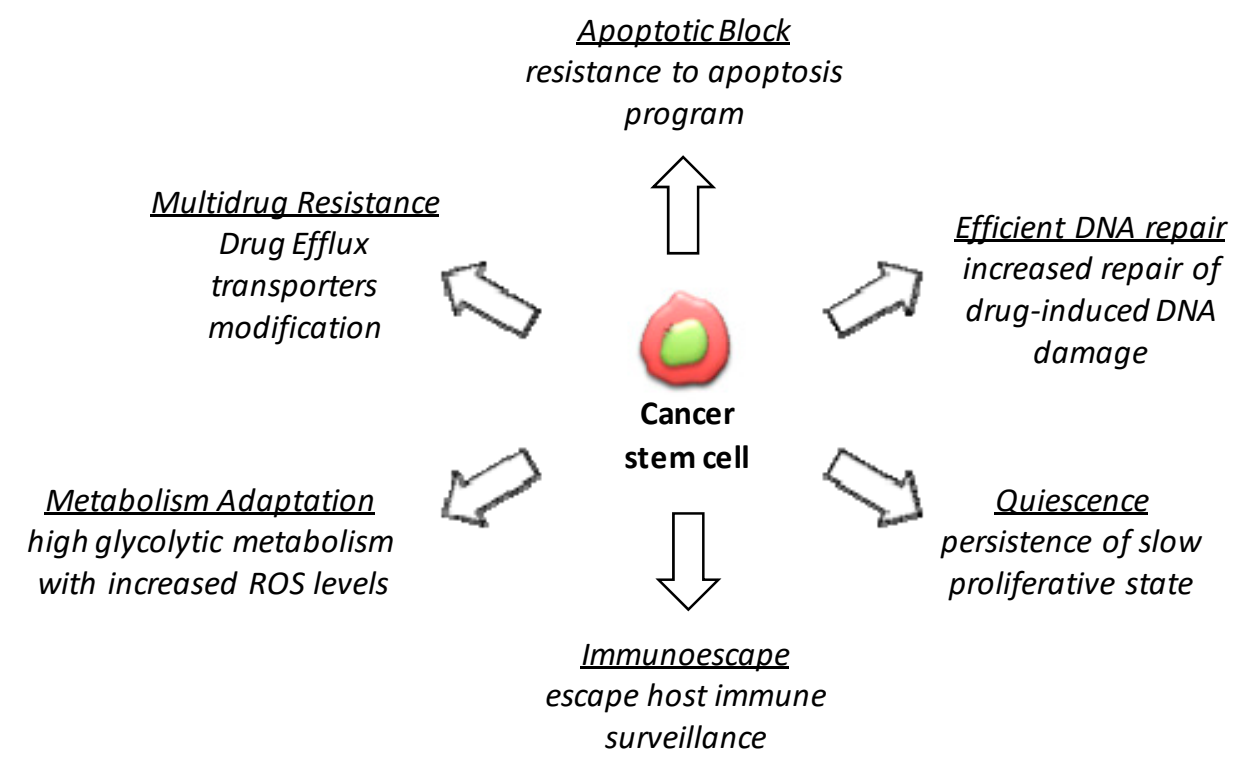

Figure 4. CSCs model of drug resistance: CSCs features mostly responsible for drug resistance.

The CSC-resistant phenotype is likely to be the result of a complex but specific mixture of molecular circuitries, and it is the complex nature of this phenomenon that explains the difficulties encountered in trying to overcome drug resistance by targeting this specific cell population.

\subsection{Multidrug Resistance}

Over 40 years ago, multidrug resistance, the high expression of drug efflux pumps, such as ATP-binding cassette $(\mathrm{ABC})$ transporter family proteins, was the first described innate resistance mechanism. Overexpression of ABCB1 confers cancer cell resistance to multiple drugs (i.e., DNA-toxic antitumor agents, reactive oxygen species -ROS- inducers), including colchicine, doxorubicin, etoposide, vinblastine and paclitaxel [74]. The critical role of ABC transporters in CSC drug resistance was reported by Chau et al. in c-Kit+ ovarian CSCs. The authors demonstrated that $\mathrm{Wnt} / \beta$-catenin regulates ABCG2 expression and resistance to cisplatin/paclitaxel. LEF/TCF binding sites are within the $A B C G 2$ gene promoter, indicating that $A B C G 2$ is a transcriptional target of $\beta$-catenin [75].

Moreover, in a prospective clinical study of 142 CRC patients, Guo et al. found that ABCB5 mRNA transcripts are significantly enriched in patient peripheral blood specimens compared with those in non-CRC controls and correlate with CRC disease progression. Notably, ABCB5 regulates CRC invasiveness, at least in part by enhancing AXL receptor tyrosine kinase signaling [76]. Additionally, in glioblastoma and melanoma, high expression of drug efflux pumps, such as ABCG2 and ABCB5, is reported in CSCs $[77,78]$.

\subsection{Apoptosis}

In addition to other mechanisms, CSC resistance to drug cytotoxicity is commonly associated with intrinsic or acquired defects and/or inefficient signaling in either the extrinsic or intrinsic pathway of apoptosis. Regarding the extrinsic pathway, lung, pancreatic, breast and glioma CSC models exhibit resistance to TRAIL-induced apoptosis by genetic and epigenetic silencing of pro-apoptotic factors, such as caspase 8 or c-FLIP, or by upregulation of TRAIL-R2 receptor, as reviewed by Fulda [79]. Regarding the intrinsic pathway, the role of Bcl-2 family members in tumorigenesis and cancer cell survival has been known for a long time, and its effects on CSC biology are well described. Bcl-2 is highly expressed in CD44 $4^{+} / \mathrm{CD} 24^{-/ \text {low }}$ breast CSCs [80] and in quiescent leukemic CD34 ${ }^{+}$progenitor 
cells [81]. Similarly, in colon CSCs, high levels of Bcl-xL activity were found in a BH3 mimetic screen [82]. Reductions of Bcl-xL expression resulted in increased sensitivity to oxaliplatin and 5-fluorouracil (5-FU) [83]. Other members of the Bcl-2 family can be involved in CSC apoptotic escape, such as MCL-1, that was found to be downregulated by MiR-519d in cisplatin-resistance breast CSCs [84]. However, it is clear that the plethora of intrinsic and extrinsic apoptosis factors involved in the fine-tuning of the apoptotic process could be affected. Indeed, Rouhrazi et al., performing a quantitative real-time polymerase chain reaction (qRT-PCR) screen for 84 key apoptosis-related genes in zoledronic acid-resistant $\mathrm{CD} 133^{+} / \mathrm{CD}_{4} 4^{+}$prostate $\mathrm{CSC}$, showed significant over/underexpression of a cluster of anti-apoptotic and pro-apoptotic genes [85]. Our group confirmed the increase in expression of antiapoptotic proteins in another preclinical model of zoledronic acid resistant prostate cancer cells in which the acquisition of CSCs features has been described. Interestingly, activation of the p38-MAPK in these cells was found to be a crucial mechanism in the regulation of several biological processes, such as antiapoptotic, prosurvival, proinflammatory and proangiogenic events, as well as EMT and invasion [86,87]. Similarly, a proteomic analysis of colonosphere cultures derived from resection specimens of liver metastases in patients with colon cancer highlighted that 20 of 32 proteins upregulated two-fold in CSCs were classified as regulating "Cell Death" [88]. From this perspective, in contrast to the observed CSC high apoptotic threshold, only combination therapies and drugs with pleiotropic effects could be effective at targeting the multiple resistance mechanisms.

\subsection{Alteration of DNA Damage Repair System}

Since radiotherapy and the majority of chemotherapeutic agents induce DNA damage, perturbation of the DNA damage repair system is another well-described mechanism of CSCs to escape genotoxic effects. As reviewed by Vitale et al. various molecular alterations lead to a robust DNA damage response (DDR) in CSCs compared with the relatively more differentiated malignant cells in glioblastoma, breast, lung and CRC [73]. However, each CSC could establish a specific alteration that increases the basal dependence on specific DDR components for proliferation and survival. Moreover, each DDR protein is under the control of several factors and in turn modulates several phenomena such as ATM (ataxia-telangiectasia mutated). Indeed, Bao et al. highlight that the CSC population exhibits an upregulation of phosphorylated ATM, Chk2, RAD51 and RAD17, either at baseline or in response to radiation [89]. Moreover, Carruthers et al. indicated that CSCs possessed ATM-independent mechanisms for activation and maintenance of the G2/M checkpoint, whereas differentiated tumor cell populations appeared to be more reliant on ATM function for G2/M checkpoint integrity [90]. In addition, Zhang et al. showed that ZEB1 participated in an ATM-dependent mechanism in the DDR response in breast CSCs by stabilizing CHK1 [91].

\subsection{Quiescence State}

In addition to a robust DDR, CSCs display a persistent quiescence state. The notion that standard chemotherapeutic resistance results from the persistence of quiescent CSCs has emerged recently by genetic-fate mapping in several solid tumor types. A slow proliferative state is essential for the survival of cells (resistance) in the presence of oxaliplatin or temozolomide treatments in CRC and in glioblastoma, respectively [92,93]. Knowledge concerning activated or silenced mechanisms relying on this state could be useful to employ combinatorial therapeutic strategies to manipulate and to sensitize CSCs to chemotherapeutics. For example, activated TGF- $\beta$ signaling (among others, responsible for triggering cytostatic signals) drives the dormancy of CSCs in mouse squamous cell carcinoma, leading to cisplatin resistance [94]. Similarly, a subpopulation of CSCs undergoing EMT is associated with a slow proliferative state that confers resistance to anti-proliferative drugs in a model of breast and skin cancer [95]. Moreover, Soeda et al. reported that inhibition of the p38 MAPK pathway led to an increase in EGFR expression but reduced proliferation and cell death induction and promoted maintenance of an undifferentiated state [96]. Recently, it has been demonstrated that leukemia stem cells express the highest levels of enhancer of zeste homolog 1 (EZH1) and 2 (EZH2), 
two histone-lysine N-methyltransferases that mediate methylation of histone $\mathrm{H} 3$ at lysine 27 (H3K27), to maintain the quiescent state. The key role of these two enzymes was confirmed, showing that inactivation of EZH1/2 eradicated quiescent leukemia stem cells, inducing cell cycle progression and differentiation [97]. Notably, EZH2 was also associated with radioresistance of glioma stem cells [98] as well as $\mathrm{CD} 24^{-/ \text {low }} \mathrm{CD} 44^{+}$population amplification in breast cancer upon treatment [99].

\subsection{Metabolism Adaptation}

In recent years, conventional wisdom indicates that CSC metabolism adaptation could play a main role in chemoresistance and radioresistance. Metabolism based on oxidative phosphorylation is crucial for the generation of energy needed to support the maintenance of tumors; however, this process also produces reactive oxygen species (ROS), which have the potential to cause stem cell dysfunction. For this reason, CSCs usually grow in a hypoxic niche and employ a glycolytic metabolism $[100,101]$. Additionally, CSCs are characterized by increased ROS levels, reduced oxidative damage and, thus, longer survival, potentially due to a combination of mechanisms that arise in the tumor, including the modulation of multiple antioxidative enzyme systems or redox-sensitive signaling pathways, such as NRF2, NF-kB, c-Jun, and HIFs, leading to increased expression of antioxidant molecules, as recently reviewed in detail by our group [102].

Another altered metabolic feature described in the CSC subpopulation is the high glycolytic metabolism recently demonstrated to be related to the high mitochondrial mass in MCF-7 breast cancer cells [103]. In detail, an unbiased proteomic approach has allowed the establishment that mitochondrial proteins are among the most strongly upregulated in cells overexpressing WNT1 and FGF3, which are responsible for the stemness phenotype. Interestingly, the mito-high MCF7 cells are also resistant to paclitaxel, resulting in little or no DNA damage [103]. Moreover, an enrichment in mitochondrial content has been associated with a higher DNA repair capacity in human breast cancer stem cells, suggesting that an increased mitochondrial mass may enable CSCs to cope efficiently with the action of certain anticancer drugs [104]. In line with these findings, a metabolic profile of CD34 $4^{+}$and CD34chronic myeloid leukemia (CML) cells, derived from fourindividuals by recording steady-state levels of 70 metabolites through liquid chromatography-mass spectrometry (LC-MS), highlighted a selective increase in glucose oxidation and anaplerosis, the process of replenishment of depleted metabolic pathway intermediates, in CML cells resistant to imatinib treatment [105].

\subsection{Immune Evasion}

Finally, a recently described CSC-resistance feature is immune evasion. CSCs have evolved sophisticated strategies to escape host immune surveillance that are targets of current therapeutic efforts (as reviewed by Fiori and Maccalli) [106,107]. A bioinformatic approach using The Cancer Genome Atlas (TCGA) revealed an enrichment of tumor-intrinsic WNT/ $\beta$-catenin signaling in non-T cell inflamed tumors, providing a strong rationale for the development of pharmacologic inhibitors of this pathway with the aim of restoring immune cell infiltration and augmenting the immunotherapeutic response [108]. Molecularly, Agudo et al. showed that cycling epithelial stem cells, including $\mathrm{Lgr}^{+}$intestinal stem cells, as well as ovary and mammary stem cells, were eliminated by activated $\mathrm{T}$ cells, but quiescent stem cells in the hair follicle and muscle were resistant to T cell killing. Mechanistically, the authors highlighted that the quiescent stem cells downregulated the antigen presentation machinery, including MHC class I and TAP proteins, through the trans-activator NLRC5 [109]. Similarly, the slow-cycling CSC subpopulation in CRC, with the loss of the major histocompatibility complex by overexpression of costimulation molecules and CSC-specific antigens, were resistant to the cytotoxic effect of dendritic and cytokine-induced killer cells [110]. Interestingly, Peng et al. found that myeloid-derived suppressor cells (MDSC) promoted tumor formation by enhancing breast CSC-like properties as well as by suppressing T cell activation, claiming a cross-talk between MDSC and breast CSCs. Specifically, MDSC inducing IL6-dependent phosphorylation of STAT3 and activation of NOTCH through nitric oxide lead to prolonged STAT3 activation in CSCs [111]. However, our knowledge about specific 
immunological properties of distinct CSC populations is still limited and requires further study to implement new targetingtherapeutic strategies.

Overall, these observations suggest that CSCs have several ways to escape anti-tumor approaches and that it is critical to identify CSC-specific alterations for targeting within a single tumor or rather to use drugs with pleiotropic effects to successfully target this difficult to kill subpopulation.

\section{HDAC Inhibitors Are Able to Overcome Chemo-Resistance}

As pleiotropic agents, HDACi can modulate a wide variety of molecules and target several related molecular pathways. Thus, it is obvious that this class of drug could affect many escape chemotoxicity strategies implemented by tumor cells and CSCs, which are described above.

Indeed, it has been demonstrated that entinostat, as a type of HDACi, reverses cisplatin resistance, among various mechanisms, by the induction of apoptosis with an increase in cleaved PARP and a decrease in MDR1 in esophageal squamous cell carcinoma [112]. Similarly, Zhao et al. observed that specific inhibition of HDAC 8 mediates the upregulation of miR-137 and inhibition of MDR1 to sensitize neuroblastoma cells to doxorubicin (Dox) [113]. In a lung cancer cell model, To et al. demonstrated that belinostat reverts cisplatin resistance by the inhibition of both ABCC2 and the DNA repair gene ERCC1 [114].

Concerning P-glycoprotein (P-gp), another crucial drug efflux transporter, although it has been reported that HDACi upregulates P-gp in colorectal cancer cells through STAT3 induction and ABCB1 posttranscriptional stabilization [115], Tomono et al. demonstrated that HDACi inhibited Snail-induced activation of P-gp in lung cancer Snail-overexpressing cells [116]. Moreover, in squamous carcinoma cell lines, Chikamatsu et al. reported that the expression of CSC markers, such as CD44 and ABCG2, decreased upon vorinostat and TSA treatment and that the combination of these HDACi with cisplatin or docetaxel had a synergistic cytotoxic effect [117].

As pointed out above, HDACi usually work as sensitizers and modulators of the entire gene pattern, synergizing with several chemotherapeutics and molecular targeted agents. Thus, the doses used in in vitro and in vivo experiments are not expected to provide clear apoptosis induction. Nevertheless, Aztopal et al. reported that relatively low doses $(2.5$ and $5 \mathrm{mM})$ of VPA prevented mammosphere formation, inducing apoptosis [118]. Similarly, Di Pompo et al. reported that new compounds with selective HDACi activity affect CSCs generated from three different histotypes of human sarcomas, inducing, among others, apoptosis [119]. The author demonstrated that concurrent class I and IIb HDAC inhibition is crucial to obtain anticancer effects. In pancreatic CSCs, vorinostat epigenetically restores the expression of miR-34a, leading to apoptosis through caspase-3/7 activation [120]. Moreover, HDAC1 inhibition contributes to NANOG-mediated TRIM17 and NOXA gene expression, leading to a downregulation of antiapoptotic MCL-1, conferring immuno- and chemo-sensitization [121].

Since a clear characterization of CSCs has not yet been defined completely, we believe that the majority of findings regarding overcoming chemoresistance were not described in a specific cell subpopulation; therefore, we have also reviewed the literature on HDACi and their ability to sensitize resistance in subpopulations in many cancer types regardless of stem-like features.

Fluoropyrimidine-based therapy still represents a classic therapeutic strategy in several solid tumors, such as colorectal, breast and pancreatic cancers; however, chemo-resistance remains a big open question to resolve. Resistance to 5-FU or to its pro-drugs may result from deficient drug uptake, alterations of targets, activation of DNA repair pathways, resistance to apoptosis andalterations of the tumor microenvironment.

We and others have previously demonstrated synergistic antitumor effects of different HDACi in combination with fluoropyrimidines in different tumors, such as breast, colorectal $[48,122-125]$ and head and neck squamous cell carcinomas (HNSCC) [126]. Our results demonstrated that the synergistic interaction between HDACi and 5-FU is dependent on both the downregulation of thymidylate synthase (TS), the key enzyme in the mechanism of action of 5-FU, and on the upregulation of thymidine phosphorylase (TP), the key enzyme converting capecitabine to 5-FU. Interestingly, HDAC3 is the 
HDAC isoform principally involved in TP upregulation. These observations could be clinically relevant since HDAC3 hasrecently emerged as a critical anticancer target [127-129], and more selective HDAC3 inhibitors may have a more favorable side-effect profile compared with class-I or non-selective HDACi. Intrinsic or acquired resistance to 5-FU is often related to TS protein overexpression. Indeed, high levels of TS expression have been correlated with poorer overall patient survival in several tumors [130]. Interestingly, we have previously demonstrated a synergistic antitumor effect of vorinostat with 5-FU in CRC cells selected for resistance to 5-FU (HT29FU cells) and in cells carrying an amplification of the TS gene (H630-R10 cells), suggesting a potential mechanism by which vorinostat may overcome the resistance to 5-FU [122]. Similarly, we recently showed that VPA/capecitabine combination treatment synergizes with radiotherapy (RT), confirming the modulation of both TS and TP protein levels by VPA in CRC models, even in the presence of RT [48]. Based on these data, a phase $1 / 2$ study is currently ongoing exploring VPA at an antiepileptic dosage, in combination with capecitabine, during preoperative radiotherapy in locally advanced rectal cancers patients (V-shoRT-R3 trial) [131]. Notably, data from the completed phase 1 of the study support the feasibility of VPA in combination with chemoradiotherapy [132].

In the same context, Huang et al. demonstrated that TSA was able to decrease colon CSC properties and, in combination with 5-FU, suppress colon cancer viability in vitro and colon tumorigenesis in vivo [133].

Another challenging class of chemotherapeutics is represented by the "platinum complexes", which includes anticancer drugs such as oxaliplatin, cisplatin and carboplatin. Cisplatin is currently employed for several tumors, such as testicular, ovarian, bladder, head and neck, esophageal, small and non-small-cell lung, cervical, stomach and others, regiments containing oxaliplatin, with or without a biologic agents in combination, are the optimal choice for metastatic CRC treatment, leading to sufficient disease reduction and allowing patients to become eligible for resection of metastatic diseases.

However, cisplatin or oxaliplatin treatments are associated with drug resistance and several adverse side effects. For these reasons, a combinational strategy aimed to revert resistance, improve outcomes and reduce side effects, could be of great benefit. Unpublished results from our group demonstrated that VPA induces cellular differentiation and sensitization of colorectal CSCs to oxaliplatin. In details, by using CRC primary spheroid cultures, transduced with a TOP-GFP Wnt reporter, we monitored apoptosis and cell proliferation in both differentiated cells and CSCs within the same population, treated with VPA alone and/or standard chemotherapy [50]. Based on these preliminary results, a randomized phase II trial has been designed by our group to evaluate whether the combination of VPA with bevacizumab and oxaliplatin/fluoropyrimidine regimens (mFOLFOX6/mOXXEL) prolongs progression-free survival (PFS) compared with bevacizumab and oxaliplatin/fluoropyrimidine regimens alone, as the first-line treatment in patients with metastatic CRC with mutation of RAS (Revolution Trial-Randomized phase II study of VPA in combination with bevacizumab and Oxaliplatin/fLUoropyrimidine regimens in patients with ras-mutated metastaTIc cOlorectal cancer). Correlative studies will be performed on patient materials to study the impact of the treatment on the CSCs population.

Cisplatin resistance has been reported in HNSCC cells to be related to enhanced stem cell properties, tumor metastasis, and increased HDACs expression [134]. Wang et al. demonstrated that cisplatin treatment, but not paclitaxel and doxorubicin treatment, result in the enrichment of CSCs, conferring multidrug resistance in NSCLC cell lines by the induction of TRIB1 and HDACs [135]. It has been demonstrated that TRIB1 enhances histone deacetylase 1 (HDAC1)-mediated p53 deacetylation and decreases DNA binding of p53, decreasing its tumor suppressor activity [136]. Moreover, high levels of TRIB1 show a significantly poorer prognosis in CRC patients, in NSCLC cisplatin-treated patients and in a Chinese Han population with pancreatic cancer $[135,137,138]$. In metastatic NSCLC, pancreatic and bladder cancer cisplatin treatment is associated with gemcitabine. In this regard, it has been described that the pan-HDACi CG200745, decreasing the transcript for multidrug resistance protein (MRP) 4, a member of the MRP/ABCC subfamily of the ATP-binding cassette, controls drug efflux and 
sensitivity in gemcitabine-resistant pancreatic cancer cells [139], for which gemcitabine-based regimens are still the major treatment. Moreover, the inhibition of HDACs 1, 7 and 8 by TSA or vorinostat results in an upregulation of e-cadherin in PDAC cells and downregulation of Oct-4, Sox-2, and Nanog, as well as inhibition of PDAC tumor sphere formation, resulting in a strong potentiation of gemcitabine therapeutic activity [16]. Interestingly, overexpression of HDAC7 has been demonstrated in pancreatic cancer and suggested as clinical biomarker for pancreatic cancer diagnosis and prognosis [140].

Additionally, CG200745, by inducing miR-509-3p expression, selectively targets Hippo signaling in cholangiocarcinoma cells and synergistically interacts with conventional chemotherapeutic drugs, including gemcitabine, cisplatin, oxaliplatin and 5-FU, even enhancing the sensitivity of gemcitabine-resistant cholangiocarcinoma cells to these drugs [141]. However, although co-treatment of biliary tract cancer cells with HDACi, including TSA, VPA or vorinostat, and gemcitabine suppresses EMT with tolerable cytotoxicity $[62,142]$, it has also been reported that HDACi increase the expression of both e-cadherin and vimentin in different cholangiocarcinoma cell lines, suggesting that further analyses are needed before using these drugs in the clinic for the treatment of this tumor [142]. The preclinical synergistic interaction between HDACi and gemcitabine has also been described in leiomyosarcoma, for which Lopez et al. demonstrated that the selective class I/IV HDACi mocetinostat combined with gemcitabine exhibits synergistic effects in vitro and in vivo [143].

Interestingly, in a phase I study in which vorinostat was combined with carboplatin and gemcitabine in women with recurrent, platinum-sensitive epithelial ovarian, fallopian tube, or peritoneal cancer, despite no maximum tolerated dose determined due to toxicities, six of the seven patients evaluable for RECIST (Response Evaluation Criteria in Solid Tumours) assessment had partial responses (PR) [144]. These results indicate that the use of other HDACi with a better safety profile, such as VPA, could be further investigated in combination with gemcitabine and/or platinum compounds.

It has been already described in the literature that HDACi modulate the EGFR family in several ways, as also reported by our group $[145,146]$. This evidence explains how HDACi improve the EGFR-based target therapy and how they overcome the drugresistance that is commonly reported after the first anti-EGFR target therapy cycles of treatment. Indeed, Wang et al. showed that HDAC6 overexpression confers resistance to gefitinib via the stabilization of EGFR. Moreover, inhibition of HDAC 6 by CAY10603, a selective inhibitor, represses the proliferation and synergizes with gefitinib to induce apoptosis in lung adenocarcinoma cell lines, via the destabilization of EGFR [147]. In the same model of NSCLC, it has been reported that the knockdown of HDAC1 sensitize resistant cells to paclitaxel in vitro and that $\mathrm{SNOH}-3$, a selective HDAC1 inhibitor, induces apoptosis and suppresses angiogenesis in preclinical models [148]. In addition, we found that vorinostat or VPA sensitize primary NSCLC cell lines to anti-ErbB3 monoclonal antibody by modulating the EGFR family also in 2D and in 3D culture models, enriched in CSCs [47]. Interestingly, a phase I study of CUDC-101, a multitarget inhibitor of HDACs, EGFR, and HER2, in combination with chemoradiation in patients with HNSCC, showed an increase of 1.5 years in median duration of response and 9/15 patients free with increased PFS [149]. Other examples of combined treatment of HDACi with targeted drugs have also been reported. For example, Gruber et al. showed that 4SC-202, a class I HDACi, abrogates GLI activation and Hh target gene expression in both SMO-inhibitor-sensitive and -resistant cells. Significantly, it has been reported that treatment with SMO inhibitors leads to rapid and frequent development of drug resistance in basal cell carcinoma and medulloblastoma [68].

Finally, it is important to highlight that, despite a good and durable clinical benefit obtained by immune checkpoint blockers (ICB) in several tumors, particularly "hot" or "immunogenic tumors", in other solid tumors, the responses with ICB are quite modest, representing a critical therapeutic challenge [150]. A possible solution to address such challenges could be to combine ICB with specific drugs aimed to prime the immune response and increase the tumor immune profile. Published data suggest that HDACi enhance the immunogenicity of cancer cells. Indeed, HDACi are involved in the regulation of NK cell-activating ligands, MHC class I and II molecules, elevation of NK and CD8+ cytotoxicity and proinflammatory cytokines, and modulation of Treg and Treg Foxp3 expression [151]. 
Terranova-Barberio et al. showed that HDACi treatment leads to a significant decrease in tumor growth through epigenetic priming of the immune system, with increased tumor antigen presentation and immune cell activation. Interestingly, both pan-HDACi and class-selective HDACi promote an upregulation of PD-L1 and HLA-DR in triple negative breast cancer cell models when co-cultured with peripheral blood mononuclear cells, associated with a downregulation of $\mathrm{CD}^{+}{ }^{+} \mathrm{Foxp}^{+}{ }^{+}$Treg in vitro and in vivo [152]. In line with this finding, Miyashita et al. found that the combination of low-dose VPA and gemcitabine enhances the susceptibility of the PANC-1 cell line to $\gamma \delta \mathrm{T}$ cell-mediated tumor cell lysis through the upregulation of major histocompatibility complex class 1-related chain molecules [153]. Interestingly, several phase I and II clinical trials, based on HDACi treatment in combination with immunotherapy, are recruiting with the aim to identify optimal biological dosing strategies [151]. The first results are not yet available, and additional preclinical studies need to be performed to disclose the mechanisms underlying the controversial HDACi-dependent effects.

\section{Conclusions and Future Perspectives}

In solid cancers, multiple factors contribute to the failure of commonly used therapies, leading to relapse. Here, we emphasized the aspects related to CSCs and their involvement in this phenomenon, reviewing what is known in the literature. By highlighting the pathways and mechanisms responsible for the resistance to the commonly used chemotherapeutics, we suggest that only the addition of pleiotropic molecules will target the CSCs population efficiently. From this perspective, HDACi could be among the best candidate drugs. We have reviewed the role of HDACi in solid cancers, specifically in the CSC subpopulation, and have pointed out some mechanisms by which HDACi are able to overcome drug resistance. In clinicaltrials.gov, 377 registered studies in solid tumors with HDACi were retrieved. Most of them are phase-I and phase-II trials and several are currently recruiting as a single agent or in combination therapies (Table 2). Only seven phase-III studies are reported and only one have published results (Table 3). In the latter study, the vorinostat effect was evaluated in monotherapy, in a double-blind, randomized placebo-controlled trial, involving 90 international centers and enrolling 661 patients with measurable advanced malignant pleural mesothelioma and disease progression after one or two previous systemic regimens. The study was negative, with no statistical significant difference (median overall survival of 30.7 weeks; $95 \%$ CI $26.7-36.1$ ) versus the placebo arm (27.1 weeks; 95\% 23.1-31.9) [154] confirming negative results obtained by this class of agent in monotherapy in several solid tumor types [155]. Another phase -III trial (ClinicalTrial.gov identifier: NCT00473889) exploring the combination of vorinostat plus carboplatin and paclitaxel in NSCLC patients was terminated due to negative results and increased toxicity, although a phase II trial demonstrated that vorinostat was able to improve the efficacy of chemotherapy [156]. Even as single agent, drug-induced side-effects of HDACi were observed, associated with several toxicities including cardiotoxicities, hematological and gastrointestinal toxicities [157]. However, despite being able to affect a multitude of physiological cellular process, thus being potentially very toxic, several HDACi have gained FDA approval for use in hematological malignancies [155].

Table 2. Phase and status of HDACi clinical trials: clinical trials registered in https://clinicaltrials.gov/ in solid tumors with HDACi.

\begin{tabular}{|c|c|c|c|c|c|c|c|c|c|}
\hline & Recruiting & $\begin{array}{l}\text { Active, Not } \\
\text { Recruiting }\end{array}$ & $\begin{array}{c}\text { Not Yet } \\
\text { Recruiting }\end{array}$ & Completed & Terminated & Suspended & Withdrawn & $\begin{array}{c}\text { Unknown } \\
\text { Status }\end{array}$ & Sum \\
\hline Early Phase 1 & 2 & 0 & 0 & 0 & 0 & 0 & 1 & 1 & 4 \\
\hline Phase 1 & 24 & 34 & 8 & 109 & 45 & 2 & 5 & 3 & 230 \\
\hline Phase 3 & 1 & 2 & 0 & 1 & 1 & 0 & 0 & 2 & 7 \\
\hline $\begin{array}{c}\text { Not } \\
\text { Applicable }\end{array}$ & 0 & 1 & 0 & 4 & 0 & 0 & 1 & 0 & 6 \\
\hline
\end{tabular}


Table 3. Phase-III HDACi clinical trials: characteristics of Seven phase-III clinical trials registered in https://clinicaltrials.gov/ that involve HDACi.

\begin{tabular}{|c|c|c|c|c|c|c|}
\hline Phase & Title & Status & Completion Date & Description & Condition & Url \\
\hline Phase 3 & $\begin{array}{l}\text { Hydralazine Valproate for } \\
\text { Ovarian Cancer }\end{array}$ & Unknown status & December 2009 & $\begin{array}{l}\text { Randomized, double-blind phase III trial. A total of } 211 \\
\text { patients (alpha } 0.5 \text {, power } 0.8 \text { ) with cisplatin-resistant } \\
\text { recurrent or persistent cancer will be randomized to } \\
\text { topotecan + placebo or topotecan + hydralazine + } \\
\text { valproate for } 6 \text { courses every } 4 \text { weeks. }\end{array}$ & Ovarian Cancer & $\begin{array}{l}\text { https://ClinicalTrials.gov/ } \\
\text { show/NCT00533299 }\end{array}$ \\
\hline Phase 3 & $\begin{array}{l}\text { Hydralazine Valproate for } \\
\text { Cervical Cancer }\end{array}$ & Unknown status & December 2010 & $\begin{array}{l}\text { Randomized, double-blind phase III trial. A total of } 143 \\
\text { patients (alph } 0.5 \text {, power } 0.8 \text { ) with metastatic, persistent or } \\
\text { recurrent cervical cancer without previous systemic } \\
\text { treatment will be randomized to cisplatin topotecan }+ \\
\text { placebo or cisplatin topotecan hydralazine valproate for } 6 \\
\text { courses every } 3 \text { weeks. }\end{array}$ & $\begin{array}{l}\text { Metastatic Cervical } \\
\text { Cancer }\end{array}$ & $\begin{array}{l}\text { https://ClinicalTrials.gov/ } \\
\text { show/NCT00532818 }\end{array}$ \\
\hline Phase 3 & $\begin{array}{c}\text { Anticancer Activity of } \\
\text { Nicotinamide on Lung } \\
\text { Cancer }\end{array}$ & Active, not recruiting & June 2020 & $\begin{array}{c}\text { Randomized Double-blinded Comparative Trial to study } \\
\text { the Add-on Activity of Combination Treatment of } \\
\text { Nicotinamide on Progression Free Survival for EGFR } \\
\text { Mutated Lung Cancer Terminal Stage Patients Being } \\
\text { Treated With Gefitinib or Erlotinib. }\end{array}$ & $\begin{array}{l}\text { Non-Small-Cell Lung } \\
\text { Carcinoma }\end{array}$ & $\begin{array}{l}\text { https://ClinicalTrials.gov/ } \\
\text { show/NCT02416739 }\end{array}$ \\
\hline Phase 3 & $\begin{array}{l}\text { Exemestane With or Without } \\
\text { Entinostat in Treating } \\
\text { Patients With Recurrent } \\
\text { Hormone Receptor-Positive } \\
\text { Breast Cancer That is Locally } \\
\text { Advanced or Metastatic }\end{array}$ & Active, not recruiting & - & $\begin{array}{l}\text { Randomized phase III trial studies exemestane and } \\
\text { entinostat to see how well they work compared to } \\
\text { exemestane alone in treating patients with hormone } \\
\text { receptor-positive breast cancer that has spread to nearby } \\
\text { tissue or lymph nodes or another place in the body. }\end{array}$ & Breast Adenocarcinoma & $\begin{array}{l}\text { https://ClinicalTrials.gov/ } \\
\text { show/NCT02115282 }\end{array}$ \\
\hline Phase 3 & $\begin{array}{l}\text { Exemestane With or Without } \\
\text { Entinostat in Chinese } \\
\text { Patients With Hormone } \\
\text { Receptor-Positive, Locally } \\
\text { Advanced or Metastatic } \\
\text { Breast Cancer }\end{array}$ & Recruiting & August 2021 & $\begin{array}{l}\text { A Randomized Phase III Clinical Study of } \\
\text { Entinostat/Placebo in Combination With Exemestane in } \\
\text { Chinese Patients With Hormone Receptor-positive } \\
\text { Advanced Breast Cancer. }\end{array}$ & $\begin{array}{l}\text { Advanced Breast } \\
\text { Carcinoma }\end{array}$ & $\begin{array}{l}\text { https://ClinicalTrials.gov/ } \\
\text { show/NCT03538171 }\end{array}$ \\
\hline Phase 3 & $\begin{array}{l}\text { A Clinical Trial of Vorinostat } \\
\text { (MK0683, SAHA) in } \\
\text { Combination With FDA } \\
\text { Approved Cancer Drugs in } \\
\text { Patients With Advanced } \\
\text { Non-Small Cell Lung Cancer } \\
\text { (NSCLC)(0683-056) }\end{array}$ & Terminated & December 2008 & $\begin{array}{l}\text { A Phase II/III Randomized, Double-Blind Study of } \\
\text { Paclitaxel Plus Carboplatin in Combination With } \\
\text { Vorinostat or Placebo in Patients With Stage IIIB (With } \\
\text { Pleural Effusion) or Stage IV Non-Small-Cell Lung Cancer } \\
\text { (NSCLC). }\end{array}$ & $\begin{array}{c}\text { Stage IIIB or IV } \\
\text { Non-Small Cell Lung } \\
\text { Cancer }\end{array}$ & $\begin{array}{l}\text { https://ClinicalTrials.gov/ } \\
\text { show/NCT00473889 }\end{array}$ \\
\hline Phase 3 & $\begin{array}{c}\text { Suberoylanilide Hydroxamic } \\
\text { Acid (Vorinostat, MK-0683) } \\
\text { Versus Placebo in Advanced } \\
\text { Malignant Pleural } \\
\text { Mesothelioma (0683-014 } \\
\text { AM5, EXT1) }\end{array}$ & Completed & November 2011 & $\begin{array}{l}\text { A Phase III, Randomized, Double-Blind, } \\
\text { Placebo-Controlled Trial of Oral Suberoylanilide } \\
\text { Hydroxamic Acid (Vorinostat, MK-0683) in Patients With } \\
\text { Advanced Malignant Pleural Mesothelioma Previously } \\
\text { Treated With Systemic Chemotherapy. }\end{array}$ & $\begin{array}{l}\text { Mesothelioma/Lung } \\
\text { Cancer }\end{array}$ & $\begin{array}{l}\text { https://ClinicalTrials.gov/ } \\
\text { show/NCT00128102 }\end{array}$ \\
\hline
\end{tabular}


Moreover, we strongly believe that HDACi should be use in clinical practice as biological modifiers and not as cytotoxic drugs. Consequently, by contrast with clinical trials conducted so far, low doses of these drugs should be used to avoid direct cytotoxic effects. In addition, we believe that the therapeutic window of this class of drug is only in combination with standard chemotherapeutics.

On these bases, further clinical and preclinical investigations should be conducted to better disclose the mechanisms by which HDACi modulate several signaling pathways in different tumors. In summary, as highlighted in this review, the promising data obtained until now could represent the foundation to test novel combinatorial therapeutic strategies, where HDACi would be combined with commonly used drugs to improve therapeutic efficacy in solid cancer tumors.

Author Contributions: Conceptualization, M.S.R., E.D.G. and A.B.; software, M.S.R.; writing—original draft preparation, M.S.R., E.D.G. and A.B.; writing—review and editing M.S.R., E.D.G. and A.B.; visualization, M.S.R.; funding acquisition, M.S.R. and A.B.

Funding: This research was funded by grants to Alfredo Budillon by the Italian Ministry of Health (RF-2011-02346914). Maria Serena Roca is supported by a triennial AIRC Fellowship (AIRC id. 21113).

Conflicts of Interest: The authors declare no conflict of interest.

\section{References}

1. Burrell, R.A.; Swanton, C. Tumour heterogeneity and the evolution of polyclonal drug resistance. Mol. Oncol. 2014, 8, 1095-1111. [CrossRef] [PubMed]

2. Meacham, C.E.; Morrison, S.J. Tumour heterogeneity and cancer cell plasticity. Nature 2013, 501, $328-337$. [CrossRef] [PubMed]

3. O'Connor, J.P.; Rose, C.J.; Waterton, J.C.; Carano, R.A.; Parker, G.J.; Jackson, A. Imaging intratumor heterogeneity: Role in therapy response, resistance, and clinical outcome. Clin. Cancer Res. 2015, 21, 249-257. [CrossRef] [PubMed]

4. Greaves, M.; Maley, C.C. Clonal evolution in cancer. Nature 2012, 481, 306-313. [CrossRef] [PubMed]

5. Siravegna, G.; Mussolin, B.; Buscarino, M.; Corti, G.; Cassingena, A.; Crisafulli, G.; Ponzetti, A.; Cremolini, C.; Amatu, A.; Lauricella, C.; et al. Clonal evolution and resistance to EGFR blockade in the blood of colorectal cancer patients. Nat. Med. 2015, 21, 795-801. [CrossRef] [PubMed]

6. Clevers, H. The cancer stem cell: Premises, promises and challenges. Nat. Med. 2011, 17, 313-319. [CrossRef]

7. Medemas, J.P. Cancer stem cells: The challenges ahead. Nat. Cell Biol. 2013, 15, 338-344. [CrossRef]

8. De Smedt, E.; Lui, H.; Maes, K.; De Veirman, K.; Menu, E.; Vanderkerken, K.; De Bruyne, E. The epigenome in multiple myeloma: Impact on tumor cell plasticity and drug response. Front. Oncol. 2018, 8, 566. [CrossRef]

9. Jones, P.A.; Issa, J.P.; Baylin, S. Targeting the cancer epigenome for therapy. Nat. Rev. Genet. 2016, 17, 630-641. [CrossRef]

10. Wainwright, E.N.; Scaffidi, P. Epigenetics and cancer stem cells: Unleashing, hijacking, and restricting cellular plasticity. Trends Cancer 2017, 3, 372-386. [CrossRef]

11. Budillon, A.; Di Gennaro, E.; Bruzzese, F.; Rocco, M.; Manzo, G.; Caraglia, M. Histone deacetylase inhibitors: A new wave of molecular targeted anticancer agents. Recent Pat. Anticancer Drug Discov. 2007, 2, 119-134. [CrossRef] [PubMed]

12. Liu, N.; Li, S.; Wu, N.; Cho, K.S. Acetylation and deacetylation in cancer stem-like cells. Oncotarget 2017, 8, 89315-89325. [CrossRef] [PubMed]

13. Sulaiman, A.; Sulaiman, B.; Khouri, L.; McGarry, S.; Nessim, C.; Arnaout, A.; Li, X.; Addison, C.; Dimitroulakos, J.; Wang, L. Both bulk and cancer stem cell subpopulations in triple-negative breast cancer are susceptible to Wnt, HDAC, and ER $\alpha$ coinhibition. FEBS Lett. 2016, 590, 4606-4616. [CrossRef] [PubMed]

14. West, A.C.; Johnstone, R.W. New and emerging HDAC inhibitors for cancer treatment. J. Clin. Investig. 2014, 124, 30-39. [CrossRef] [PubMed]

15. Witt, A.E.; Lee, C.W.; Lee, T.I.; Azzam, D.J.; Wang, B.; Caslini, C.; Petrocca, F.; Grosso, J.; Jones, M.; Cohick, E.B.; et al. Identification of a cancer stem cell-specific function for the histone deacetylases, HDAC1 and HDAC7, in breast and ovarian cancer. Oncogene 2017, 36, 1707-1720. [CrossRef] [PubMed] 
16. Cai, M.H.; Xu, X.G.; Yan, S.L.; Sun, Z.; Ying, Y.; Wang, B.K.; Tu, Y.X. Depletion of HDAC1, 7 and 8 by histone deacetylase inhibition confers elimination of pancreatic cancer stem cells in combination with gemcitabine. Sci. Rep. 2018, 8, 1621. [CrossRef]

17. Chao, M.W.; Chu, P.C.; Chuang, H.C.; Shen, F.H.; Chou, C.C.; Hsu, E.C.; Himmel, L.E.; Huang, H.L.; Tu, H.J.; Kulp, S.K.; et al. Non-epigenetic function of HDAC8 in regulating breast cancer stem cells by maintaining Notch1 protein stability. Oncotarget 2016, 7, 1796-1807. [CrossRef]

18. An, P.; Li, J.; Lu, L.; Wu, Y.; Ling, Y.; Du, J.; Chen, Z.; Wang, H. Histone deacetylase 8 triggers the migration of triple negative breast cancer cells via regulation of YAP signals. Eur. J. Pharmacol. 2019, 845, 16-23. [CrossRef]

19. Zimberlin, C.D.; Lancini, C.; Sno, R.; Rosekrans, S.L.; McLean, C.M.; Vlaming, H.; van den Brink, G.R.; Bots, M.; Medema, J.P.; Dannenberg, J.H. HDAC1 and HDAC2 collectively regulate intestinal stem cell homeostasis. FASEB J. 2015, 29, 2070-2080. [CrossRef]

20. Jamaladdin, S.; Kelly, R.D.; O’Regan, L.; Dovey, O.M.; Hodson, G.E.; Millard, C.J.; Portolano, N.; Fry, A.M.; Schwabe, J.W.; Cowley, S.M. Histone deacetylase (HDAC) 1 and 2 are essential for accurate cell division and the pluripotency of embryonic stem cells. Proc. Natl. Acad Sci. USA 2014, 111, 9840-9845. [CrossRef]

21. Montgomery, R.L.; Davis, C.A.; Potthoff, M.J.; Haberland, M.; Fielitz, J.; Qi, X.; Hill, J.A.; Richardson, J.A.; Olson, E.N. Histone deacetylases 1 and 2 redundantly regulate cardiac morphogenesis, growth, and contractility. Genes Dev. 2007, 21, 1790-1802. [CrossRef] [PubMed]

22. Yusoff, S.I.; Roman, M.; Lai, F.Y.; Eagle-Hemming, B.; Murphy, G.J.; Kumar, T.; Wozniak, M. Systematic review and meta-analysis of experimental studies evaluating the organ protective effects of histone deacetylase inhibitors. Transl. Res. 2019, 205, 1-16. [CrossRef] [PubMed]

23. Liu, J.; Lichtenberg, T.; Hoadley, K.A.; Poisson, L.M.; Lazar, A.J.; Cherniack, A.D.; Kovatich, A.J.; Benz, C.C.; Levine, D.A.; Lee, A.V.; et al. An integrated TCGA pan-cancer clinical data resource to drive high-quality survival outcome analytics. Cell 2018, 173, 400-416. [CrossRef] [PubMed]

24. Fodde, R.; Brabletz, T. Wnt/beta-catenin signaling in cancer stemness and malignant behavior. Curr. Opin. Cell Biol. 2007, 19, 150-158. [CrossRef] [PubMed]

25. Barker, N.; Clevers, H. Mining the Wnt pathway for cancer therapeutics. Nat. Rev. Drug Discov. 2006, 5, 997-1014. [CrossRef] [PubMed]

26. Reya, T.; Clevers, H. Wnt signalling in stem cells and cancer. Nature 2005, 434, 843-850. [CrossRef]

27. Taha, Z.; Janse van Rensburg, H.J.; Yang, X. The Hippo pathway: Immunity and cancer. Cancers 2018, 10, 94. [CrossRef]

28. Nguyen, L.T.; Tretiakova, M.S.; Silvis, M.R.; Lucas, J.; Klezovitch, O.; Coleman, I.; Bolouri, H.; Kutyavin, V.I.; Morrissey, C.; True, L.D.; et al. ERG activates the YAP1 transcriptional program and induces the development of age-related prostate tumors. Cancer Cell 2015, 27, 797-808. [CrossRef]

29. Zhang, L.; Yang, S.; Chen, X.; Stauffer, S.; Yu, F.; Lele, S.M.; Fu, K.; Datta, K.; Palermo, N.; Chen, Y.; et al. The hippo pathway effector YAP regulates motility, invasion, and castration-resistant growth of prostate cancer cells. Mol. Cell Biol. 2015, 35, 1350-1362. [CrossRef]

30. Bourgeais, J.; Gouilleux-Gruart, V.; Gouilleux, F. Oxidative metabolism in cancer: A STAT affair? Jak-Stat 2013, 2, e25764. [CrossRef]

31. Ouedraogo, Z.G.; Biau, J.; Kemeny, J.L.; Morel, L.; Verrelle, P.; Chautard, E. Role of STAT3 in genesis and progression of human malignant gliomas. Mol. Neurobiol. 2017, 54, 5780-5797. [CrossRef] [PubMed]

32. Ganguly, D.; Fan, M.; Yang, C.H.; Zbytek, B.; Finkelstein, D.; Roussel, M.F.; Pfeffer, L.M. The critical role that STAT3 plays in glioma-initiating cells: STAT3 addiction in glioma. Oncotarget 2018, 9, 22095-22112. [CrossRef] [PubMed]

33. West, A.J.; Tsui, V.; Stylli, S.S.; Nguyen, H.P.T.; Morokoff, A.P.; Kaye, A.H.; Luwor, R.B. The role of interleukin-6-STAT3 signalling in glioblastoma. Oncol. Lett. 2018, 16, 4095-4104. [CrossRef]

34. Kohsaka, S.; Wang, L.; Yachi, K.; Mahabir, R.; Narita, T.; Itoh, T.; Tanino, M.; Kimura, T.; Nishihara, H.; Tanaka, S. STAT3 inhibition overcomes temozolomide resistance in glioblastoma by downregulating MGMT expression. Mol. Cancer Ther. 2012, 11, 1289-1299. [CrossRef] [PubMed]

35. Walker, S.R.; Xiang, M.; Frank, D.A. STAT3 activity and function in cancer: Modulation by STAT5 and miR-146b. Cancers 2014, 6, 958-968. [CrossRef] [PubMed]

36. Yusra; Semba, S.; Yokozaki, H. Biological significance of tumor budding at the invasive front of human colorectal carcinoma cells. Int. J. Oncol. 2012, 41, 201-210. 
37. Yu, Y.; Kanwar, S.S.; Patel, B.B.; Oh, P.S.; Nautiyal, J.; Sarkar, F.H.; Majumdar, A.P. MicroRNA-21 induces stemness by downregulating transforming growth factor beta receptor 2 (TGFbetaR2) in colon cancer cells. Carcinogenesis 2012, 33, 68-76. [CrossRef] [PubMed]

38. Venkatesh, V.; Nataraj, R.; Thangaraj, G.S.; Karthikeyan, M.; Gnanasekaran, A.; Kaginelli, S.B.; Kuppanna, G.; Kallappa, C.G.; Basalingappa, K.M. Targeting Notch signalling pathway of cancer stem cells. Stem Cell Investig. 2018, 5, 5. [CrossRef]

39. Katoh, M. Networking of WNT, FGF, Notch, BMP, and Hedgehog signaling pathways during carcinogenesis. Stem Cell Rev. 2007, 3, 30-38. [CrossRef]

40. Jiang, J.; Hui, C.C. Hedgehog signaling in development and cancer. Dev. Cell 2008, 15, 801-812. [CrossRef]

41. Takebe, N.; Miele, L.; Harris, P.J.; Jeong, W.; Bando, H.; Kahn, M.; Yang, S.X.; Ivy, S.P. Targeting Notch, Hedgehog, and Wnt pathways in cancer stem cells: Clinical update. Nat. Rev. Clin. Oncol. 2015, 12, 445-464. [CrossRef]

42. Duan, Z.H.; Wang, H.C.; Zhao, D.M.; Ji, X.X.; Song, M.; Yang, X.J.; Cui, W. Cooperatively transcriptional and epigenetic regulation of sonic hedgehog overexpression drives malignant potential of breast cancer. Cancer Sci. 2015, 106, 1084-1091. [CrossRef] [PubMed]

43. Krop, I.; Demuth, T.; Guthrie, T.; Wen, P.Y.; Mason, W.P.; Chinnaiyan, P.; Butowski, N.; Groves, M.D.; Kesari, S.; Freedman, S.J.; et al. Phase I pharmacologic and pharmacodynamic study of the gamma secretase (Notch) inhibitor MK-0752 in adult patients with advanced solid tumors. J. Clin. Oncol. 2012, 30, 2307-2313. [CrossRef] [PubMed]

44. Pattabiraman, D.R.; Weinberg, R.A. Tackling the cancer stem cells-What challenges do they pose? Nat. Rev. Drug Discov. 2014, 13, 497-512. [CrossRef] [PubMed]

45. Munoz, P.; Iliou, M.S.; Esteller, M. Epigenetic alterations involved in cancer stem cell reprogramming. Mol. Oncol. 2012, 6, 620-636. [CrossRef] [PubMed]

46. Yoshida, M.; Kijima, M.; Akita, M.; Beppu, T. Potent and specific inhibition of mammalian histone deacetylase both in vivo and in vitro by trichostatin A. J. Biol. Chem. 1990, 265, 17174-17179.

47. Ciardiello, C.; Roca, M.S.; Noto, A.; Bruzzese, F.; Moccia, T.; Vitagliano, C.; Di Gennaro, E.; Ciliberto, G.; Roscilli, G.; Aurisicchio, L.; et al. Synergistic antitumor activity of histone deacetylase inhibitors and anti-ErbB3 antibody in NSCLC primary cultures via modulation of ErbB receptors expression. Oncotarget 2016, 7, 19559-19574. [CrossRef]

48. Terranova-Barberio, M.; Pecori, B.; Roca, M.S.; Imbimbo, S.; Bruzzese, F.; Leone, A.; Muto, P.; Delrio, P.; Avallone, A.; Budillon, A.; et al. Synergistic antitumor interaction between valproic acid, capecitabine and radiotherapy in colorectal cancer: Critical role of p53. J. Exp. Clin. Cancer Res. 2017, 36, 177. [CrossRef]

49. Salvador, M.A.; Wicinski, J.; Cabaud, O.; Toiron, Y.; Finetti, P.; Josselin, E.; Lelievre, H.; Kraus-Berthier, L.; Depil, S.; Bertucci, F.; et al. The histone deacetylase inhibitor abexinostat induces cancer stem cells differentiation in breast cancer with low Xist expression. Clin. Cancer Res. 2013, 19, 6520-6531. [CrossRef]

50. Roca, M.S.; Experimental Pharmacology Unit, Istituto Nazionale Tumori-IRCCS-Fondazione G. Pascale, Naples, Italy. Unpublished work. 2019.

51. Wang, Y.; Liu, M.; Jin, Y.; Jiang, S.; Pan, J. In vitro and in vivo anti-uveal melanoma activity of JSL-1, a novel HDAC inhibitor. Cancer Lett. 2017, 400, 47-60. [CrossRef]

52. Li, Y.; Zhang, X.; Polakiewicz, R.D.; Yao, T.P.; Comb, M.J. HDAC6 is required for epidermal growth factor-induced beta-catenin nuclear localization. J. Biol. Chem. 2008, 283, 12686-12690. [CrossRef]

53. Yu, S.; Cai, X.; Wu, C.; Liu, Y.; Zhang, J.; Gong, X.; Wang, X.; Wu, X.; Zhu, T.; Mo, L.; et al. Targeting HSP90-HDAC6 regulating network implicates precision treatment of breast cancer. Int. J. Biol. Sci. 2017, 13, 505-517. [CrossRef] [PubMed]

54. Li, L.; Fang, R.; Liu, B.; Shi, H.; Wang, Y.; Zhang, W.; Zhang, X.; Ye, L. Deacetylation of tumor-suppressor MST1 in Hippo pathway induces its degradation through HBXIP-elevated HDAC6 in promotion of breast cancer growth. Oncogene 2016, 35, 4048-4057. [CrossRef] [PubMed]

55. Shan, B.; Yao, T.P.; Nguyen, H.T.; Zhuo, Y.; Levy, D.R.; Klingsberg, R.C.; Tao, H.; Palmer, M.L.; Holder, K.N.; Lasky, J.A. Requirement of HDAC6 for transforming growth factor- beta1-induced epithelial-mesenchymal transition. J. Biol. Chem. 2008, 283, 21065-21073. [CrossRef] [PubMed] 
56. Sferra, R.; Pompili, S.; Festuccia, C.; Marampon, F.; Gravina, G.L.; Ventura, L.; Di Cesare, E.; Cicchinelli, S.; Gaudio, E.; Vetuschi, A. The possible prognostic role of histone deacetylase and transforming growth factor beta/Smad signaling in high grade gliomas treated by radio-chemotherapy: A preliminary immunohistochemical study. Eur. J. Histochem. 2017, 61, 2732. [CrossRef] [PubMed]

57. Yang, W.; Liu, Y.; Gao, R.; Yu, H.; Sun, T. HDAC6 inhibition induces glioma stem cells differentiation and enhances cellular radiation sensitivity through the SHH/Gli1 signaling pathway. Cancer Lett. 2018, 415, 164-176. [CrossRef] [PubMed]

58. Tang, Y.N.; Ding, W.Q.; Guo, X.J.; Yuan, X.W.; Wang, D.M.; Song, J.G. Epigenetic regulation of Smad2 and Smad3 by profilin-2 promotes lung cancer growth and metastasis. Nat. Commun. 2015, 6, 8230. [CrossRef] [PubMed]

59. Canettieri, G.; Di Marcotullio, L.; Greco, A.; Coni, S.; Antonucci, L.; Infante, P.; Pietrosanti, L.; De Smaele, E.; Ferretti, E.; Miele, E.; et al. Histone deacetylase and Cullin3-REN(KCTD11) ubiquitin ligase interplay regulates Hedgehog signalling through Gli acetylation. Nat. Cell Biol. 2010, 12, 132-142. [CrossRef] [PubMed]

60. Wei, M.; Mao, S.; Lu, G.; Li, L.; Lan, X.; Huang, Z.; Chen, Y.; Zhao, M.; Zhao, Y.; Xia, Q. Valproic acid sensitizes metformin-resistant human renal cell carcinoma cells by upregulating $\mathrm{H} 3$ acetylation and EMT reversal. BMC Cancer 2018, 18, 434. [CrossRef] [PubMed]

61. Iannelli, F.; Experimental Pharmacology Unit, Istituto Nazionale Tumori-IRCCS-Fondazione G. Pascale, Naples, Italy. Unpublished work. 2019.

62. Sun, G.; Mackey, L.V.; Coy, D.H.; Yu, C.Y.; Sun, L. The histone deacetylase inhibitor vaproic acid induces cell growth arrest in hepatocellular carcinoma cells via suppressing notch signaling. J. Cancer 2015, 6, 996-1004. [CrossRef] [PubMed]

63. Cui, Y.; Ma, W.; Lei, F.; Li, Q.; Su, Y.; Lin, X.; Lin, C.; Zhang, X.; Ye, L.; Wu, S.; et al. Prostate tumour overexpressed-1 promotes tumourigenicity in human breast cancer via activation of Wnt/beta-catenin signalling. J. Pathol. 2016, 239, 297-308. [CrossRef] [PubMed]

64. Sakamoto, T.; Kobayashi, S.; Yamada, D.; Nagano, H.; Tomokuni, A.; Tomimaru, Y.; Noda, T.; Gotoh, K.; Asaoka, T.; Wada, H.; et al. A histone deacetylase inhibitor suppresses epithelial-mesenchymal transition and attenuates chemoresistance in biliary tract cancer. PLoS ONE 2016, 11, e0145985. [CrossRef] [PubMed]

65. Zhang, H.; Liu, L.; Liu, C.; Pan, J.; Lu, G.; Zhou, Z.; Chen, Z.; Qian, C. Notch3 overexpression enhances progression and chemoresistance of urothelial carcinoma. Oncotarget 2017, 8, 34362-34373. [CrossRef] [PubMed]

66. Fan, C.W.; Yarravarapu, N.; Shi, H.; Kulak, O.; Kim, J.; Chen, C.; Lum, L. A synthetic combinatorial approach to disabling deviant Hedgehog signaling. Sci. Rep. 2018, 8, 1133. [CrossRef] [PubMed]

67. Li, L.; Fan, B.; Zhang, L.H.; Xing, X.F.; Cheng, X.J.; Wang, X.H.; Guo, T.; Du, H.; Wen, X.Z.; Ji, J.F. Trichostatin A potentiates TRAIL-induced antitumor effects via inhibition of ERK/FOXM1 pathway in gastric cancer. Tumour Biol. 2016, 37, 10269-10278. [CrossRef] [PubMed]

68. Gruber, W.; Peer, E.; Elmer, D.P.; Sternberg, C.; Tesanovic, S.; Del Burgo, P.; Coni, S.; Canettieri, G.; Neureiter, D.; Bartz, R.; et al. Targeting class I histone deacetylases by the novel small molecule inhibitor 4SC-202 blocks oncogenic hedgehog-GLI signaling and overcomes smoothened inhibitor resistance. Int. J. Cancer 2018, 142, 968-975. [CrossRef] [PubMed]

69. Debeb, B.G.; Lacerda, L.; Xu, W.; Larson, R.; Solley, T.; Atkinson, R.; Sulman, E.P.; Ueno, N.T.; Krishnamurthy, S.; Reuben, J.M.; et al. Histone deacetylase inhibitors stimulate dedifferentiation of human breast cancer cells through WNT/beta-catenin signaling. Stem Cells 2012, 30, 2366-2377. [CrossRef] [PubMed]

70. Yardley, D.A.; Ismail-Khan, R.R.; Melichar, B.; Lichinitser, M.; Munster, P.N.; Klein, P.M.; Cruickshank, S.; Miller, K.D.; Lee, M.J.; Trepel, J.B. Randomized phase II, double-blind, placebo-controlled study of exemestane with or without entinostat in postmenopausal women with locally recurrent or metastatic estrogen receptor-positive breast cancer progressing on treatment with a nonsteroidal aromatase inhibitor. J. Clin. Oncol. 2013, 31, 2128-2135. [PubMed]

71. Chan, E.; Chiorean, E.G.; O’Dwyer, P.J.; Gabrail, N.Y.; Alcindor, T.; Potvin, D.; Chao, R.; Hurwitz, H. Phase I/II study of mocetinostat in combination with gemcitabine for patients with advanced pancreatic cancer and other advanced solid tumors. Cancer Chemother. Pharmacol. 2018, 81, 355-364. [CrossRef] [PubMed]

72. Szakacs, G.; Paterson, J.K.; Ludwig, J.A.; Booth-Genthe, C.; Gottesman, M.M. Targeting multidrug resistance in cancer. Nat. Rev. Drug Discov. 2006, 5, 219-234. [CrossRef] [PubMed] 
73. Vitale, I.; Manic, G.; De Maria, R.; Kroemer, G.; Galluzzi, L. DNA damage in stem cells. Mol. Cell 2017, 66, 306-319. [CrossRef]

74. Robey, R.W.; Pluchino, K.M.; Hall, M.D.; Fojo, A.T.; Bates, S.E.; Gottesman, M.M. Revisiting the role of ABC transporters in multidrug-resistant cancer. Nat. Rev. Cancer 2018, 18, 452-464. [CrossRef] [PubMed]

75. Chau, W.K.; Ip, C.K.; Mak, A.S.; Lai, H.C.; Wong, A.S. c-Kit mediates chemoresistance and tumor-initiating capacity of ovarian cancer cells through activation of Wnt/beta-catenin-ATP-binding cassette G2 signaling. Oncogene 2013, 32, 2767-2781. [CrossRef] [PubMed]

76. Guo, Q.; Grimmig, T.; Gonzalez, G.; Giobbie-Hurder, A.; Berg, G.; Carr, N.; Wilson, B.J.; Banerjee, P.; Ma, J.; Gold, J.S.; et al. ATP-binding cassette member B5 (ABCB5) promotes tumor cell invasiveness in human colorectal cancer. J. Biol. Chem. 2018, 293, 11166-11178. [CrossRef] [PubMed]

77. Shervington, A.; Lu, C. Expression of multidrug resistance genes in normal and cancer stem cells. Cancer Investig. 2008, 26, 535-542. [CrossRef] [PubMed]

78. Schatton, T.; Murphy, G.F.; Frank, N.Y.; Yamaura, K.; Waaga-Gasser, A.M.; Gasser, M.; Zhan, Q.; Jordan, S.; Duncan, L.M.; Weishaupt, C.; et al. Identification of cells initiating human melanomas. Nature 2008, 451, 345-349. [CrossRef]

79. Fulda, S. Regulation of apoptosis pathways in cancer stem cells. Cancer Lett. 2013, 338, 168-173. [CrossRef] [PubMed]

80. Madjd, Z.; Mehrjerdi, A.Z.; Sharifi, A.M.; Molanaei, S.; Shahzadi, S.Z.; Asadi-Lari, M. CD44+ cancer cells express higher levels of the anti-apoptotic protein Bcl-2 in breast tumours. Cancer Immun. 2009, 9, 4.

81. Konopleva, M.; Zhao, S.; Hu, W.; Jiang, S.; Snell, V.; Weidner, D.; Jackson, C.E.; Zhang, X.; Champlin, R.; Estey, E.; et al. The anti-apoptotic genes $\mathrm{Bcl}-\mathrm{X}(\mathrm{L})$ and $\mathrm{Bcl}-2$ are over-expressed and contribute to chemoresistance of non-proliferating leukaemic CD34+ cells. Br. J. Haematol. 2002, 118, 521-534. [CrossRef]

82. Colak, S.; Zimberlin, C.D.; Fessler, E.; Hogdal, L.; Prasetyanti, P.R.; Grandela, C.M.; Letai, A.; Medema, J.P. Decreased mitochondrial priming determines chemoresistance of colon cancer stem cells. Cell Death Differ. 2014, 21, 1170-1177. [CrossRef]

83. Todaro, M.; Alea, M.P.; Di Stefano, A.B.; Cammareri, P.; Vermeulen, L.; Iovino, F.; Tripodo, C.; Russo, A.; Gulotta, G.; Medema, J.P.; et al. Colon cancer stem cells dictate tumor growth and resist cell death by production of interleukin-4. Cell Stem Cell 2007, 1, 389-402. [CrossRef]

84. Xie, Q.; Wang, S.; Zhao, Y.; Zhang, Z.; Qin, C.; Yang, X. MiR-519d impedes cisplatin-resistance in breast cancer stem cells by down-regulating the expression of MCL-1. Oncotarget 2017, 8, 22003-22013. [CrossRef] [PubMed]

85. Rouhrazi, H.; Turgan, N.; Oktem, G. Zoledronic acid overcomes chemoresistance by sensitizing cancer stem cells to apoptosis. Biotech. Histochem. 2018, 93, 77-88. [CrossRef] [PubMed]

86. Milone, M.R.; Pucci, B.; Bifulco, K.; Iannelli, F.; Lombardi, R.; Ciardiello, C.; Bruzzese, F.; Carriero, M.V.; Budillon, A. Proteomic analysis of zoledronic-acid resistant prostate cancer cells unveils novel pathways characterizing an invasive phenotype. Oncotarget 2015, 6, 5324-5341. [PubMed]

87. Milone, M.R.; Pucci, B.; Bruzzese, F.; Carbone, C.; Piro, G.; Costantini, S.; Capone, F.; Leone, A.; Di Gennaro, E.; Caraglia, M.; et al. Acquired resistance to zoledronic acid and the parallel acquisition of an aggressive phenotype are mediated by p38-MAP kinase activation in prostate cancer cells. Cell Death Dis. 2013, 4, e641. [CrossRef] [PubMed]

88. Van Houdt, W.J.; Emmink, B.L.; Pham, T.V.; Piersma, S.R.; Verheem, A.; Vries, R.G.; Fratantoni, S.A.; Pronk, A.; Clevers, H.; Borel Rinkes, I.H.; et al. Comparative proteomics of colon cancer stem cells and differentiated tumor cells identifies BIRC6 as a potential therapeutic target. Mol. Cell Proteomics 2011, 10, M111.011353. [CrossRef] [PubMed]

89. Bao, S.; Wu, Q.; McLendon, R.E.; Hao, Y.; Shi, Q.; Hjelmeland, A.B.; Dewhirst, M.W.; Bigner, D.D.; Rich, J.N. Glioma stem cells promote radioresistance by preferential activation of the DNA damage response. Nature 2006, 444, 756-760. [CrossRef] [PubMed]

90. Carruthers, R.; Ahmed, S.U.; Strathdee, K.; Gomez-Roman, N.; Amoah-Buahin, E.; Watts, C.; Chalmers, A.J. Abrogation of radioresistance in glioblastoma stem-like cells by inhibition of ATM kinase. Mol. Oncol. 2015, 9, 192-203. [CrossRef] [PubMed]

91. Zhang, P.; Wei, Y.; Wang, L.; Debeb, B.G.; Yuan, Y.; Zhang, J.; Yuan, J.; Wang, M.; Chen, D.; Sun, Y.; et al. ATM-mediated stabilization of ZEB1 promotes DNA damage response and radioresistance through CHK1. Nat. Cell Biol. 2014, 16, 864-875. [CrossRef] 
92. Kreso, A.; O’Brien, C.A.; van Galen, P.; Gan, O.I.; Notta, F.; Brown, A.M.; Ng, K.; Ma, J.; Wienholds, E.; Dunant, C.; et al. Variable clonal repopulation dynamics influence chemotherapy response in colorectal cancer. Science 2013, 339, 543-548. [CrossRef]

93. Chen, J.; Li, Y.; Yu, T.S.; McKay, R.M.; Burns, D.K.; Kernie, S.G.; Parada, L.F. A restricted cell population propagates glioblastoma growth after chemotherapy. Nature 2012, 488, 522-526. [CrossRef]

94. Oshimori, N.; Oristian, D.; Fuchs, E. TGF- $\beta$ promotes heterogeneity and drug resistance in squamous cell carcinoma. Cell 2015, 160, 963-976. [CrossRef] [PubMed]

95. Creighton, C.J.; Li, X.; Landis, M.; Dixon, J.M.; Neumeister, V.M.; Sjolund, A.; Rimm, D.L.; Wong, H.; Rodriguez, A.; Herschkowitz, J.I.; et al. Residual breast cancers after conventional therapy display mesenchymal as well as tumor-initiating features. Proc. Natl. Acad Sci. USA 2009, 106, 13820-13825. [CrossRef] [PubMed]

96. Soeda, A.; Lathia, J.; Williams, B.J.; Wu, Q.; Gallagher, J.; Androutsellis-Theotokis, A.; Giles, A.J.; Yang, C.; Zhuang, Z.; Gilbert, M.R.; et al. The p38 signaling pathway mediates quiescence of glioma stem cells by regulating epidermal growth factor receptor trafficking. Oncotarget 2017, 8, 33316-33328. [CrossRef] [PubMed]

97. Fujita, S.; Honma, D.; Adachi, N.; Araki, K.; Takamatsu, E.; Katsumoto, T.; Yamagata, K.; Akashi, K.; Aoyama, K.; Iwama, A.; et al. Dual inhibition of EZH1/2 breaks the quiescence of leukemia stem cells in acute myeloid leukemia. Leukemia 2018, 32, 855-864. [CrossRef] [PubMed]

98. Kim, S.H.; Joshi, K.; Ezhilarasan, R.; Myers, T.R.; Siu, J.; Gu, C.; Nakano-Okuno, M.; Taylor, D.; Minata, M.; Sulman, E.P.; et al. EZH2 protects glioma stem cells from radiation-induced cell death in a MELK/FOXM1-dependent manner. Stem Cell Rep. 2015, 4, 226-238. [CrossRef] [PubMed]

99. Chang, C.J.; Yang, J.Y.; Xia, W.; Chen, C.T.; Xie, X.; Chao, C.H.; Woodward, W.A.; Hsu, J.M.; Hortobagyi, G.N.; Hung, M.C. EZH2 promotes expansion of breast tumor initiating cells through activation of RAF1- $\beta$-catenin signaling. Cancer Cell 2011, 19, 86-100. [CrossRef] [PubMed]

100. Suda, T.; Takubo, K.; Semenza, G.L. Metabolic regulation of hematopoietic stem cells in the hypoxic niche. Cell Stem Cell 2011, 9, 298-310. [CrossRef]

101. Simsek, T.; Kocabas, F.; Zheng, J.; Deberardinis, R.J.; Mahmoud, A.I.; Olson, E.N.; Schneider, J.W.; Zhang, C.C.; Sadek, H.A. The distinct metabolic profile of hematopoietic stem cells reflects their location in a hypoxic niche. Cell Stem Cell 2010, 7, 380-390. [CrossRef]

102. Leone, A.; Roca, M.S.; Ciardiello, C.; Costantini, S.; Budillon, A. Oxidative stress gene expression profile correlates with cancer patient poor prognosis: Identification of crucial pathways might select novel therapeutic approaches. Oxid. Med. Cell Longev. 2017, 2017, 2597581. [CrossRef]

103. Farnie, G.; Sotgia, F.; Lisanti, M.P. High mitochondrial mass identifies a sub-population of stem-like cancer cells that are chemo-resistant. Oncotarget 2015, 6, 30472-30486. [CrossRef]

104. Prieto, J.; Leon, M.; Ponsoda, X.; Sendra, R.; Bort, R.; Ferrer-Lorente, R.; Raya, A.; Lopez-Garcia, C.; Torres, J. Early ERK1/2 activation promotes DRP1-dependent mitochondrial fission necessary for cell reprogramming. Nat. Commun. 2016, 7, 11124. [CrossRef] [PubMed]

105. Kuntz, E.M.; Baquero, P.; Michie, A.M.; Dunn, K.; Tardito, S.; Holyoake, T.L.; Helgason, G.V.; Gottlieb, E. Targeting mitochondrial oxidative phosphorylation eradicates therapy-resistant chronic myeloid leukemia stem cells. Nat. Med. 2017, 23, 1234-1240. [CrossRef] [PubMed]

106. Fiori, M.E.; Villanova, L.; De Maria, R. Cancer stem cells: At the forefront of personalized medicine and immunotherapy. Curr. Opin. Pharmacol. 2017, 35, 1-11. [CrossRef] [PubMed]

107. Maccalli, C.; Volonte, A.; Cimminiello, C.; Parmiani, G. Immunology of cancer stem cells in solid tumours. A review. Eur. J. Cancer 2014, 50, 649-655. [CrossRef] [PubMed]

108. Luke, J.J.; Bao, R.; Sweis, R.F.; Spranger, S.; Gajewski, T.F. WNT/beta-catenin pathway activation correlates with immune exclusion across human cancers. Clin. Cancer Res. 2019, 25, 3074-3083. [CrossRef]

109. Agudo, J.; Park, E.S.; Rose, S.A.; Alibo, E.; Sweeney, R.; Dhainaut, M.; Kobayashi, K.S.; Sachidanandam, R.; Baccarini, A.; Merad, M.; et al. Quiescent tissue stem cells evade immune surveillance. Immunity 2018, 48, 271-285. [CrossRef] [PubMed]

110. Wu, F.H.; Mu, L.; Li, X.L.; Hu, Y.B.; Liu, H.; Han, L.T.; Gong, J.P. Characterization and functional analysis of a slow-cycling subpopulation in colorectal cancer enriched by cell cycle inducer combined chemotherapy. Oncotarget 2017, 8, 78466-78479. [CrossRef] [PubMed] 
111. Peng, D.; Tanikawa, T.; Li, W.; Zhao, L.; Vatan, L.; Szeliga, W.; Wan, S.; Wei, S.; Wang, Y.; Liu, Y.; et al. Myeloid-derived suppressor cells endow stem-like qualities to breast cancer cells through IL6/STAT3 and NO/NOTCH cross-talk signaling. Cancer Res. 2016, 76, 3156-3165. [CrossRef]

112. Huang, X.P.; Li, X.; Situ, M.Y.; Huang, L.Y.; Wang, J.Y.; He, T.C.; Yan, Q.H.; Xie, X.Y.; Zhang, Y.J.; Gao, Y.H.; et al. Entinostat reverses cisplatin resistance in esophageal squamous cell carcinoma via down-regulation of multidrug resistance gene 1. Cancer Lett. 2018, 414, 294-300. [CrossRef]

113. Zhao, G.; Wang, G.; Bai, H.; Li, T.; Gong, F.; Yang, H.; Wen, J.; Wang, W. Targeted inhibition of HDAC8 increases the doxorubicin sensitivity of neuroblastoma cells via up regulation of miR-137. Eur. J. Pharmacol. 2017, 802, 20-26. [CrossRef]

114. To, K.K.; Tong, W.S.; Fu, L.W. Reversal of platinum drug resistance by the histone deacetylase inhibitor belinostat. Lung Cancer 2017, 103, 58-65. [CrossRef] [PubMed]

115. Wang, H.; Huang, C.; Zhao, L.; Zhang, H.; Yang, J.M.; Luo, P.; Zhan, B.X.; Pan, Q.; Li, J.; Wang, B.L. Histone deacetylase inhibitors regulate $\mathrm{P}$-gp expression in colorectal cancer via transcriptional activation and mRNA stabilization. Oncotarget 2016, 7, 49848-49858. [CrossRef]

116. Tomono, T.; Machida, T.; Kamioka, H.; Shibasaki, Y.; Yano, K.; Ogihara, T. Entinostat reverses P-glycoprotein activation in snail-overexpressing adenocarcinoma HCC827 cells. PLoS ONE 2018, 13, e0200015. [CrossRef] [PubMed]

117. Chikamatsu, K.; Ishii, H.; Murata, T.; Sakakura, K.; Shino, M.; Toyoda, M.; Takahashi, K.; Masuyama, K. Alteration of cancer stem cell-like phenotype by histone deacetylase inhibitors in squamous cell carcinoma of the head and neck. Cancer Sci. 2013, 104, 1468-1475. [CrossRef] [PubMed]

118. Aztopal, N.; Erkisa, M.; Erturk, E.; Ulukaya, E.; Tokullugil, A.H.; Ari, F. Valproic acid, a histone deacetylase inhibitor, induces apoptosis in breast cancer stem cells. Chem. Biol. Interact. 2018, 280, 51-58. [CrossRef] [PubMed]

119. Di Pompo, G.; Salerno, M.; Rotili, D.; Valente, S.; Zwergel, C.; Avnet, S.; Lattanzi, G.; Baldini, N.; Mai, A. Novel histone deacetylase inhibitors induce growth arrest, apoptosis, and differentiation in sarcoma cancer stem cells. J. Med. Chem. 2015, 58, 4073-4079. [CrossRef] [PubMed]

120. Nalls, D.; Tang, S.N.; Rodova, M.; Srivastava, R.K.; Shankar, S. Targeting epigenetic regulation of miR-34a for treatment of pancreatic cancer by inhibition of pancreatic cancer stem cells. PLoS ONE 2011, 6, e24099. [CrossRef]

121. Song, K.H.; Choi, C.H.; Lee, H.J.; Oh, S.J.; Woo, S.R.; Hong, S.O.; Noh, K.H.; Cho, H.; Chung, E.J.; Kim, J.H.; et al. HDAC1 upregulation by NANOG promotes multidrug resistance and a stem-like phenotype in immune edited tumor cells. Cancer Res. 2017, 77, 5039-5053. [CrossRef]

122. Di Gennaro, E.; Bruzzese, F.; Pepe, S.; Leone, A.; Delrio, P.; Subbarayan, P.R.; Avallone, A.; Budillon, A. Modulation of thymidilate synthase and p53 expression by HDAC inhibitor vorinostat resulted in synergistic antitumor effect in combination with 5FU or raltitrexed. Cancer Biol. Ther. 2009, 8, 782-791. [CrossRef]

123. Di Gennaro, E.; Piro, G.; Chianese, M.I.; Franco, R.; Di Cintio, A.; Moccia, T.; Luciano, A.; de Ruggiero, I.; Bruzzese, F.; Avallone, A.; et al. Vorinostat synergises with capecitabine through upregulation of thymidine phosphorylase. Br. J. Cancer 2010, 103, 1680-1691. [CrossRef]

124. Terranova-Barberio, M.; Roca, M.S.; Zotti, A.I.; Leone, A.; Bruzzese, F.; Vitagliano, C.; Scogliamiglio, G.; Russo, D.; D'Angelo, G.; Franco, R.; et al. Valproic acid potentiates the anticancer activity of capecitabine in vitro and in vivo in breast cancer models via induction of thymidine phosphorylase expression. Oncotarget 2016, 7, 7715-7731. [CrossRef] [PubMed]

125. Fazzone, W.; Wilson, P.M.; Labonte, M.J.; Lenz, H.J.; Ladner, R.D. Histone deacetylase inhibitors suppress thymidylate synthase gene expression and synergize with the fluoropyrimidines in colon cancer cells. Int. J. Cancer 2009, 125, 463-473. [CrossRef] [PubMed]

126. Piro, G.; Roca, M.S.; Bruzzese, F.; Carbone, C.; Iannelli, F.; Leone, A.; Volpe, M.G.; Budillon, A.; Di Gennaro, E. Vorinostat potentiates cisplatin-5-fluorouracil combination by inhibiting chemotherapy-induced EGFR nuclear translocation and increasing cisplatin uptake. Mol. Cancer Ther. 2019, in press.

127. Muller, B.M.; Jana, L.; Kasajima, A.; Lehmann, A.; Prinzler, J.; Budczies, J.; Winzer, K.J.; Dietel, M.; Weichert, W.; Denkert, C. Differential expression of histone deacetylases HDAC1, 2 and 3 in human breast cancer-Overexpression of HDAC2 and HDAC3 is associated with clinicopathological indicators of disease progression. BMC Cancer 2013, 13, 215. [CrossRef] [PubMed] 
128. Spurling, C.C.; Godman, C.A.; Noonan, E.J.; Rasmussen, T.P.; Rosenberg, D.W.; Giardina, C. HDAC3 overexpression and colon cancer cell proliferation and differentiation. Mol. Carcinog. 2008, 47, 137-147. [CrossRef] [PubMed]

129. Minami, J.; Suzuki, R.; Mazitschek, R.; Gorgun, G.; Ghosh, B.; Cirstea, D.; Hu, Y.; Mimura, N.; Ohguchi, H.; Cottini, F.; et al. Histone deacetylase 3 as a novel therapeutic target in multiple myeloma. Leukemia 2014, 28, 680-689. [CrossRef] [PubMed]

130. Ackland, S.P.; Clarke, S.J.; Beale, P.; Peters, G.J. Thymidylate synthase inhibitors. Cancer Chemother. Biol. Response Modif. 2002, 20,1-36. [PubMed]

131. Avallone, A.; Piccirillo, M.C.; Delrio, P.; Pecori, B.; Di Gennaro, E.; Aloj, L.; Tatangelo, F.; D'Angelo, V.; Granata, C.; Cavalcanti, E.; et al. Phase 1/2 study of valproic acid and short-course radiotherapy plus capecitabine as preoperative treatment in low-moderate risk rectal cancer-V-shoRT-R3 (Valproic acid-Short Radiotherapy-Rectum 3rd trial). BMC Cancer 2014, 14, 875. [CrossRef] [PubMed]

132. Avallone, A.; Istituto Nazionale Tumori-IRCCS-Fondazione G. Pascale, 80131, Naples, Italy. Unpublished work. 2019.

133. Huang, T.H.; Wu, S.Y.; Huang, Y.J.; Wei, P.L.; Wu, A.T.; Chao, T.Y. The identification and validation of Trichosstatin A as a potential inhibitor of colon tumorigenesis and colon cancer stem-like cells. Am. J. Cancer Res. 2017, 7, 1227-1237.

134. Kumar, B.; Yadav, A.; Lang, J.C.; Teknos, T.N.; Kumar, P. Suberoylanilide hydroxamic acid (SAHA) reverses chemoresistance in head and neck cancer cells by targeting cancer stem cells via the downregulation of nanog. Genes Cancer 2015, 6, 169-181.

135. Wang, L.; Liu, X.; Ren, Y.; Zhang, J.; Chen, J.; Zhou, W.; Guo, W.; Wang, X.; Chen, H.; Li, M.; et al. Cisplatin-enriching cancer stem cells confer multidrug resistance in non-small cell lung cancer via enhancing TRIB1/HDAC activity. Cell Death Dis. 2017, 8, e2746. [CrossRef]

136. Miyajima, C.; Inoue, Y.; Hayashi, H. Pseudokinase tribbles 1 (TRB1) negatively regulates tumor-suppressor activity of p53 through p53 deacetylation. Biol. Pharm. Bull. 2015, 38, 618-624. [CrossRef] [PubMed]

137. Wang, Y.; Wu, N.; Pang, B.; Tong, D.; Sun, D.; Sun, H.; Zhang, C.; Sun, W.; Meng, X.; Bai, J.; et al. TRIB1 promotes colorectal cancer cell migration and invasion through activation MMP-2 via FAK/Src and ERK pathways. Oncotarget 2017, 8, 47931-47942. [CrossRef] [PubMed]

138. Lu, X.X.; Hu, J.J.; Fang, Y.; Wang, Z.T.; Xie, J.J.; Zhan, Q.; Deng, X.X.; Chen, H.; Jin, J.B.; Peng, C.H.; et al. A case-control study indicates that the TRIB1 gene is associated with pancreatic cancer. Genet. Mol. Res. 2014, 13, 6142-6147. [CrossRef] [PubMed]

139. Lee, H.S.; Park, S.B.; Kim, S.A.; Kwon, S.K.; Cha, H.; Lee, D.Y.; Ro, S.; Cho, J.M.; Song, S.Y. A novel HDAC inhibitor, CG200745, inhibits pancreatic cancer cell growth and overcomes gemcitabine resistance. Sci. Rep. 2017, 7, 41615. [CrossRef] [PubMed]

140. Ouaissi, M.; Sielezneff, I.; Silvestre, R.; Sastre, B.; Bernard, J.P.; Lafontaine, J.S.; Payan, M.J.; Dahan, L.; Pirro, N.; Seitz, J.F.; et al. High histone deacetylase 7 (HDAC7) expression is significantly associated with adenocarcinomas of the pancreas. Ann. Surg. Oncol. 2008, 15, 2318-2328. [CrossRef] [PubMed]

141. Jung, D.E.; Park, S.B.; Kim, K.; Kim, C.; Song, S.Y. CG200745, an HDAC inhibitor, induces anti-tumour effects in cholangiocarcinoma cell lines via miRNAs targeting the Hippo pathway. Sci. Rep. 2017, 7, 10921. [CrossRef] [PubMed]

142. Wang, J.H.; Lee, E.J.; Ji, M.; Park, S.M. HDAC inhibitors, trichostatin A and valproic acid, increase Ecadherin and vimentin expression but inhibit migration and invasion of cholangiocarcinoma cells. Oncol. Rep. 2018, 40, 346-354.

143. Lopez, G.; Braggio, D.; Zewdu, A.; Casadei, L.; Batte, K.; Bid, H.K.; Koller, D.; Yu, P.; Iwenofu, O.H.; Strohecker, A.; et al. Mocetinostat combined with gemcitabine for the treatment of leiomyosarcoma: Preclinical correlates. PLoS ONE 2017, 12, e0188859. [CrossRef]

144. Matulonis, U.; Berlin, S.; Lee, H.; Whalen, C.; Obermayer, E.; Penson, R.; Liu, J.; Campos, S.; Krasner, C.; Horowitz, N. Phase I study of combination of vorinostat, carboplatin, and gemcitabine in women with recurrent, platinum-sensitive epithelial ovarian, fallopian tube, or peritoneal cancer. Cancer Chemother. Pharmacol. 2015, 76, 417-423. [CrossRef]

145. Bruzzese, F.; Leone, A.; Rocco, M.; Carbone, C.; Piro, G.; Caraglia, M.; Di Gennaro, E.; Budillon, A. HDAC inhibitor vorinostat enhances the antitumor effect of gefitinib in squamous cell carcinoma of head and neck by modulating ErbB receptor expression and reverting EMT. J. Cell Physiol. 2011, 226, 2378-2390. [CrossRef] 
146. Leone, A.; Roca, M.S.; Ciardiello, C.; Terranova-Barberio, M.; Vitagliano, C.; Ciliberto, G.; Mancini, R.; Di Gennaro, E.; Bruzzese, F.; Budillon, A. Vorinostat synergizes with EGFR inhibitors in NSCLC cells by increasing ROS via up-regulation of the major mitochondrial porin VDAC1 and modulation of the c-Myc-NRF2-KEAP1 pathway. Free Radic. Biol. Med. 2015, 89, 287-299. [CrossRef] [PubMed]

147. Wang, Z.; Tang, F.; Hu, P.; Wang, Y.; Gong, J.; Sun, S.; Xie, C. HDAC6 promotes cell proliferation and confers resistance to gefitinib in lung adenocarcinoma. Oncol. Rep. 2016, 36, 589-597. [CrossRef] [PubMed]

148. Wang, L.; Li, H.; Ren, Y.; Zou, S.; Fang, W.; Jiang, X.; Jia, L.; Li, M.; Liu, X.; Yuan, X.; et al. Targeting HDAC with a novel inhibitor effectively reverses paclitaxel resistance in non-small cell lung cancer via multiple mechanisms. Cell Death Dis. 2016, 7, e2063. [CrossRef] [PubMed]

149. Galloway, T.J.; Wirth, L.J.; Colevas, A.D.; Gilbert, J.; Bauman, J.E.; Saba, N.F.; Raben, D.; Mehra, R.; Ma, A.W.; Atoyan, R.; et al. A phase I study of CUDC-101, a multitarget inhibitor of HDACs, EGFR, and HER2, in combination with chemoradiation in patients with head and neck squamous cell carcinoma. Clin. Cancer Res. 2015, 21, 1566-1573. [CrossRef] [PubMed]

150. Vonderheide, R.H. The immune revolution: A case for priming, not checkpoint. Cancer Cell 2018, 33, 563-569. [CrossRef] [PubMed]

151. Terranova-Barberio, M.; Thomas, S.; Munster, P.N. Epigenetic modifiers in immunotherapy: A focus on checkpoint inhibitors. Immunotherapy 2016, 8, 705-719. [CrossRef] [PubMed]

152. Terranova-Barberio, M.; Thomas, S.; Ali, N.; Pawlowska, N.; Park, J.; Krings, G.; Rosenblum, M.D.; Budillon, A.; Munster, P.N. HDAC inhibition potentiates immunotherapy in triple negative breast cancer. Oncotarget 2017, 8, 114156-114172. [CrossRef]

153. Miyashita, T.; Miki, K.; Kamigaki, T.; Makino, I.; Tajima, H.; Nakanuma, S.; Hayashi, H.; Takamura, H.; Fushida, S.; Ahmed, A.K.; et al. Low-dose valproic acid with low-dose gemcitabine augments MHC class I-related chain A/B expression without inducing the release of soluble MHC class I-related chain A/B. Oncol. Lett. 2017, 14, 5918-5926. [CrossRef]

154. Krug, L.M.; Kindler, H.L.; Calvert, H.; Manegold, C.; Tsao, A.S.; Fennell, D.; Ohman, R.; Plummer, R.; Eberhardt, W.E.; Fukuoka, K.; et al. Vorinostat in patients with advanced malignant pleural mesothelioma who have progressed on previous chemotherapy (VANTAGE-014): A phase 3, double-blind, randomised, placebo-controlled trial. Lancet Oncol. 2015, 16, 447-456. [CrossRef]

155. Suraweera, A.; O'Byrne, K.J.; Richard, D.J. Combination therapy with histone deacetylase inhibitors (HDACi) for the treatment of cancer: Achieving the full therapeutic potential of HDACi. Front. Oncol. 2018, 8, 92. [CrossRef]

156. Ramalingam, S.S.; Maitland, M.L.; Frankel, P.; Argiris, A.E.; Koczywas, M.; Gitlitz, B.; Thomas, S.; Espinoza-Delgado, I.; Vokes, E.E.; Gandara, D.R.; et al. Carboplatin and Paclitaxel in combination with either vorinostat or placebo for first-line therapy of advanced non-small-cell lung cancer. J. Clin. Oncol. 2010, 28, 56-62. [CrossRef] [PubMed]

157. Wilting, R.H.; Yanover, E.; Heideman, M.R.; Jacobs, H.; Horner, J.; van der Torre, J.; DePinho, R.A.; Dannenberg, J.H. Overlapping functions of Hdac1 and Hdac2 in cell cycle regulation and haematopoiesis. EMBO J. 2010, 29, 2586-2597. [CrossRef] [PubMed]

(C) 2019 by the authors. Licensee MDPI, Basel, Switzerland. This article is an open access article distributed under the terms and conditions of the Creative Commons Attribution (CC BY) license (http://creativecommons.org/licenses/by/4.0/). 